\title{
Religious Identity and the Provision of Public Goods: Evidence from the Indian Princely States*
}

\author{
Latika Chaudhary $^{\dagger} \quad$ Jared Rubin ${ }^{\ddagger}$
}

March 2015

\begin{abstract}
Identifying the effect of a ruler's religious identity on policy is challenging because religious identity rarely varies over time and place. We address this problem by exploiting quasi-random variation in the religion of rulers in the Indian Princely States. Using data from the 1911 census, we find that Muslim-ruled states had lower Hindu literacy but the religion of the ruler had no statistically significant impact on Muslim literacy, railroad ownership, or post office provision. These results support the hypothesis that rulers provide less public goods when religious institutions provide a substitute targeted at their co-religionists.
\end{abstract}

Keywords: Public Goods, Identity, Religion, Literacy, Railroads, Post Offices, Princely States, India, Islam, Hinduism

JEL Codes: H41, H42, N35, H75, I25, Z12

${ }^{*}$ We are grateful to Sheetal Bharat for sharing her data on colonial post offices. We also wish to thank Sascha Becker, Shameel Ahmad, Lakshmi Iyer, Saumitra Jha, Petra Moser and seminar participants at Stanford University, the 2014 Yale South Asian Economic History Conference, the 2014 ASREC, 2013 AEA and 2012 WEAI Conferences for helpful comments. Latika Chaudhary thanks the Hoover Institution for financial support through the National Fellows Program. All errors are our own.

${ }^{\dagger}$ Associate Professor, Naval Postgraduate School, Email: lhartman@nps.edu

${ }_{\ddagger}^{\ddagger}$ Associate Professor, Chapman University, Email: jrubin@chapman.edu 


\section{Introduction}

Scholars have long recognized the influence of religion on economic development. ${ }^{1}$ In recent years the focus has shifted to uncovering specific mechanisms linking the two. One important mechanism is human capital accumulation. Some studies show that religion and religious institutions have a positive impact on education. For example, Becker and Wöessmann $(2008,2009)$ find that all-Protestant counties had literacy rates that were 8 percentage points higher than all-Catholic counties, and they ascribe this difference to past, institutionalized incentives to acquire human capital. Botticini and Eckstein (2005, 2007) make a similar case connecting Jewish human capital to long-run economic outcomes. Other studies such as Berman (2000) highlight the negative impact of religion on education; in his study, ultraOrthodox Jews spend too much time attending school (Yeshiva) rather than working, leaving many in relative poverty. Although these studies highlight the importance of religion for human capital development, the debate on the underlying mechanisms continues.

Our paper relates to this literature by studying whether the religious identity of unelected rulers impacts education. We exploit an exceptionally unique historical setting: the Indian Princely States. British colonial rule in India was comprised of territories under direct rule, British India and territories under indirect colonial rule, the Princely States. The latter states were under the direct rule of hereditary rulers who controlled local affairs while the British controlled foreign policy. Princely States were spread all over the subcontinent with substantial heterogeneity in the religion of the rulers. A majority of the states were ruled by Hindus (80\%), but a non-trivial number were ruled by Muslims (15\%) and Sikhs (5\%). Importantly, the religion of the ruler was not strictly a function of regional religious affiliation; many Muslim kings ruled over predominantly Hindu populations, while many Hindu kings ruled over Muslim populations. Many states were established in the $18^{\text {th }}$ century by mercenaries and warriors that offered military protection to the local population. In these conquest states the rulers were often unconnected to the local population, suggesting a degree of randomness in the religion of the ruler because the ruler's religion was often not a function of economic, religious, or demographic characteristics of the people.

Using data from the 1911 and 1931 census of India, we find that states with Muslim rulers had lower literacy on average than states with non-Muslim, mostly Hindu rulers. It could

\footnotetext{
${ }^{1}$ The classic examples are Weber's (1905) Protestant Ethic hypothesis and Tawney's (1926) rebuttal. More recently, economists have made all sorts of connections mapping some aspect of religion to economic development. See, for instance, Greif (1994, 2006), Grier (1997), Barro and McCleary (2003), Guiso et al. (2003), Botticini and Eckstein (2005, 2007), Noland (2005), Arruñada (2010), Rubin (2011), Kuran (2011), Spenkuch (2011), Jha (2013), Bhalotra et al. (2014), Cantoni (2014), Greif and Rubin (2015), and Iyigun (2015).
} 
be that Muslim-ruled states were negatively selected, which would explain the lower levels of literacy. For example, if Muslim-ruled states were poorer and less developed on average than non-Muslim states, then income differences may be driving the results and not the Muslim identity of the ruler. To test this possibility we control for differences in geography and development, and we find similar results. Next, we decompose literacy by religion. We find that Muslim rulers did not impact Muslim literacy - the coefficient on Muslim ruler is small, positive and statistically insignificant. But, Muslim rulers had a large, negative, and statistically significant impact on Hindu literacy. In addition, we explore the impact of Muslim rulers on the provision of railways, an expensive infrastructure undertaking in this period. We find no differential impact of Muslim rulers on the availability or quality of railways. Interestingly, revenues are the key determinant of whether states funded railways.

We rely on a simple theoretical model to account for these patterns. In our model a ruler provides a non-excludable public good and has a preference for providing for his coreligionists, ceteris paribus. Two results follow from this framework. The first (and more trivial) result is that a ruler provides more public goods when a greater share of his subjects are his co-religionists, regardless of the properties of the public good. The second, more nuanced result is that the existence of substitutes provided by private markets affects the provision of the public good, but only if the private good is excludable by religion. The idea is that if the good is also provided privately to the ruler's co-religionists, the ruler provides less of the public good, since it is non-excludable and his co-religionists receive lower marginal utility from its provision. ${ }^{2}$ An example of such a quasi-public good is education, which is provided by the state and the private sector, but discrimination on the basis of religion is more likely in the private sector, especially in a historical context when many private schools were also religious schools. ${ }^{3}$

By the early $20^{\text {th }}$ century, Muslim religious schools were more prevalent than Hindu religious schools in colonial India. The model therefore predicts that Hindus living in Muslimruled states would have worse educational outcomes because Muslim rulers would spend

\footnotetext{
${ }^{2}$ This insight is consistent with the recent literature suggesting that religious expenditure and public good provision are substitutes (Gill and Lundsgaarde 2004; Hungerman 2005; Hungerman and Gruber 2007), but the mechanism is different; those works suggest that public expenditure crowds out religious expenditure, while our model suggests the reverse. This insight is also consistent with Franck and Rainer (2012), who find that rulers exhibit ethnic favoritism in sub-Saharan Africa, favoritism is an important factor in determining education outcomes, and the presence of favoritism is mitigated when citizens belong primarily to one dominant religion.

${ }^{3}$ Another example of a public good that is excludable by religion is charity, which has traditionally been privately provided in many Christian and Islamic lands. Indeed, Huber and Stanig (2011) suggest that privately-provided charity can create voting cleavages amongst charity recipients based on whether they receive charity from the state or from religious institutions. This insight is related to the one presented in this paper, although Huber and Stanig are interested in a democratic context and we are not.
} 
less on public education. Meanwhile, the effect on Muslim education outcomes would be minimal because the private sector via Muslim religious schools makes up for the short fall. This accords with our findings above: the Hindu literacy rate is 2 to 3 percentage points lower in Muslim-ruled states, while there is no statistically significant effect of Muslim rule on Muslim literacy. Yet, we find only weak support for our other hypothesis relating public good outcomes to the share of the ruler's co-religionists. We find that literacy rates for both Hindus and Muslims are greater in Muslim-ruled regions when there is a higher share of Muslims, but the coefficients are not precisely estimated.

We use data on public schools, railways (mentioned above) and post offices to further test the theory. The Imperial Gazetteer of India (Hunter et al., 1907) records the number of public schools and enrollment as of 1903-04 for many Princely States. We combed through the history of each state in the Imperial Gazetteer extracting any information on public schools and enrollment as of 1903-04. This information was noted for many but not all the states in our sample. Consistent with our model, we find Muslim rulers are negatively correlated with public schools and enrollment. Unlike education, for which there was a privately available substitute, there were no widespread substitutes for railways or post offices, and certainly none that could be excluded by religion. Both railways and post offices were generally linked to their British Indian counterparts and were far superior to alternatives provided by the private sector. Hence, our model suggests the presence of a Muslim ruler should not influence the provision of railways or post offices. And, this is what we find. Although Muslim rulers were more likely to fund railways and provide one or more post offices, these estimates are statistically insignificant.

Clearly Princely States were not randomly assigned to Muslim rulers. Hence, we worry that Muslim ruled states are a selected sample, different from non-Muslim ruled states. For example, if Muslim ruled states were more positively selected, we would expect an upward bias on the estimate for Muslim rule, and the opposite if Muslim ruled states were negatively selected. To address such concerns we use recent matching techniques based on inverse probability weights to compare outcomes in Muslim ruled states with observationally similar Hindu ruled states. The matching results are similar to our cross-sectional regressions. In particular, we find Muslim rule has a negative and significant impact only on Hindu literacy. We find negative effects on public schools and enrollment but the coefficients are not precisely estimated.

While our model emphasizes one particular mechanism, we consider other competing explanations. The most important one is that Muslim rulers were more likely to hire local Muslims as bureaucrats to run their administration. This would suggest Hindu literacy 
was lower in Muslim-ruled states because Hindus were unlikely to serve these roles and hence Muslim rulers were unlikely to patronize public schools attended by Hindus. Much of the qualitative literature suggests both Hindu and Muslim rulers relied on outsiders for key administrative positions. This ensured local elites could not unite against the ruling family. Moreover, there was no strong religious element to these positions. Hindu kings hired non-local Muslim administrators while Muslim rulers commonly hired Hindu administrators. Finally, a pure patronage story would suggest we find both positive effects on Muslim literacy and negative effects on Hindu literacy. In contrast, we only find negative effects on Hindu literacy.

Another explanation relates to which groups converted to Islam in this period, and relatedly whether Muslim rule influenced the types of Muslims who may have migrated to the Princely States. It was not uncommon to observe Hindus convert to Islam, Christianity, and other religions during the colonial period and before. Unfortunately we lack strong quantitative evidence on who converted, when and why. This suggests the Muslim population share in 1911 may be endogenous to the religion of the ruler. If upper caste and more educated Hindus converted to Islam in Muslim ruled states to court favor and patronage, then such positive selection out of the Hindu population could account for our findings. But the historical accounts indicate conversion to Islam was more common among the lower Hindu castes suggesting if anything a negative selection into Islam. Similarly if Muslim rule attracted more educated Muslims to their states, then we should expect a positive coefficient on Muslim rule for Muslim literacy that we do not find. Although we cannot rule out all competing explanations, we believe the evidence on literacy and public goods supports our preferred theoretical mechanism.

Our paper contributes to two distinct literatures. First, a growing literature has developed on different aspects of religion and colonial rule in India. Jha (2013) finds that incidents of Hindu-Muslim conflict are significantly lower between 1850 and 1950 in medieval ports on account of interethnic complementarities. Such a legacy of ethnic tolerance continues to mitigate against conflict even today (Jha 2014). Iyer (2010) is among the first credible economic studies comparing the performance of the Princely States to areas under direct colonial rule (British India). She finds that Princely States have better economic outcomes in post-independence India with many of the differences (e.g., education) dating to the colonial period. Interestingly, she finds no differences in economic outcomes for Muslim-ruled states relative to the rest of India in the post-independence period. In separate work focusing on British India, we find districts that experienced a more recent collapse of Muslim (primarily Mughal) rule have worse literacy outcomes (Chaudhary and Rubin 2011). We 
argue this was due to the strength of religious authorities in these areas, who were better able to provide alternatives to public schools. However, the focus on British India entails there is no variation in the religion of the ruler and so in that study we could not speak to how the religious identity of a ruler affects incentives to provide public goods and literacy.

A second literature that this paper contributes to is the growing literature connecting religion to economic outcomes via religious, political, and economic institutions. This literature challenges the early-20th century tradition dating back to Weber (1905) and Tawney (1926) which suggests that there are certain aspects of religion that are either friendly (e.g., a "work ethic") or inimical (e.g., restrictions on taking interest) to economic growth. In this view, institutions are more important than the content of religion per se. That is, religious laws and authorities place constraints on the choice sets of political authorities, and these constraints are manifested in different ways depending on the institutional past. In particular, comparative works show how different institutional relationships between Muslim and non-Muslim regions led to long-run differences in financial institutions and instruments (Kuran 2005, 2011; Rubin 2010), reaction to technology (Coşgel et al. 2012a, 2012b), trade institutions (Greif 1994, 2006), and laws (Rubin 2011).

The rest of the paper is organized as follows. Section 2 reviews the historical background on Indian Princely States; Section 3 outlines our formal model relating the religion of the ruler to public good provision; Section 4 places the theoretical predictions from our model into historical context; Section 5 describes the data; Section 6 lays out the empirical strategy; Section 7 presents the results, and Section 8 concludes.

\section{Historical Background on the Princely States}

\subsection{State Formation and Relationship with British India}

The Indian Princely States were parts of South Asia that came under indirect colonial control in the $18^{\text {th }}$ and $19^{\text {th }}$ century (as opposed to areas under direct colonial rule i.e., British India). ${ }^{4}$ Per the official definition, a Princely State was a "political community, occupying a territory in India of defined boundaries, and subject to a common and responsible ruler who has actually enjoyed and exercised, as belonging to him in his own right duty recognized by the supreme authority of the British Government, any of the functions and attributes of internal sovereignty" (House of Commons 1913, p. 14). These states were ruled by hereditary kings who negotiated either official treaties or certificates of protection with the East India

\footnotetext{
${ }^{4}$ See Roy (2013) for an economic history of India in the $18^{\text {th }}$ century. He provides details on the emergence and subsequent development of Princely States in this period.
} 


\section{Company. ${ }^{5}$}

As part of these contracts, hereditary rulers deferred to the British Crown with regard to foreign policy and military related matters. They could not enter political relations with foreign countries or other Princely States without explicit permission of the Government of India (GOI). Some states were allowed to maintain a small military force for internal order and were expected to contribute troops, cavalry and other resources to colonial military efforts when necessary. In exchange, these states were allowed to manage their own internal affairs including tax collection and the provision of public services. However, the British Crown reserved the right to intervene in internal matters in "cases of grave misrule, or to prevent disputed successions or rebellion, or the dismemberment of a State by division or legacy" (House of Commons 1913, p. 15). ${ }^{6}$ We combed through individual histories of the states in the Imperial Gazetteer of India (Hunter et al. 1907) and found that just over a quarter of Princely States had been reprimanded or experienced an intervention by the Government of India as of 1904.

By the early $20^{\text {th }}$ century, there were 693 Princely States with substantial differences between them in area, population, and autonomy. The largest Princely State of Hyderabad commanded an area of 82,000 square miles and a population of over 13 million in 1912 . It had the authority to mint its own coins and was allowed to levy the death penalty on its subjects. On the other extreme, many smaller states in western India consisted of a few villages with limited judicial powers of civil or criminal enforcement. By 1911, the GOI categorized 83 states as salute states based on their importance to the British Crown. Salute states received 3 to 21 ceremonial gun salutes (i.e., gun firings) when their rulers visited the GOI capital at Delhi (Jeffrey 1978). In our regressions, we control for the number of gun salutes to capture the importance of the state to the GOI.

Princely States were scattered throughout the subcontinent with large concentrations in western and central India. As the Mughal Empire declined in the early $18^{\text {th }}$ century, many regional states emerged to replace Mughal rule. The strongest of these states (the Maratha Dominion in western India, Hyderabad in the Deccan plateau, and Mysore in southern India) wrestled for control with the East India Company. After multiple battles and alliances with regional powers, the Company emerged triumphant by the early $19^{\text {th }}$ century with the largest territories under their command. British India included the coastal

\footnotetext{
${ }^{5}$ Before the First War of Independence (also known as Indian Mutiny) in 1857, the East India Company was in control of the Indian sub-continent. Beginning in 1858 the British Crown took over control from the Company.

${ }^{6}$ Mysore is perhaps the most famous case where the GOI brought the state under direct colonial control in 1831 on account of years of mismanagement. The original Hindu rulers were restored as rulers in 1881.
} 
provinces of Bengal, Bombay, and Madras and the alluvial plains along the Ganga river valley. Most of north India also came under direct British control by the mid- $19^{\text {th }}$ century. Figure 1 shows a 1911 map of India distinguishing British India from the Princely States. ${ }^{7}$

The Company initially set up trading posts in Indian ports under the patronage of Mughal emperors. It followed that the early territories to come under British rule were along the coast. For example, Bengal, a former Mughal province and important regional state of the $18^{\text {th }}$ century, was the first region taken over by the Company in 1757 . As they gradually annexed new territory over the next 100 years, the British favored agriculturally or commercially advanced regions. Arid desserts in the west and parts of central India with low agriculture potential were intentionally left under the control of local rulers. Many such states would have been unable to survive to the $20^{\text {th }}$ century without British protection, as large states with bigger armies would have annexed the smaller states (Jeffrey 1978, Ramusack 2004). In fact, the Company intentionally kept some areas under local rule in the first phase of annexation to create a barrier between them and the strong regional states of the $18^{\text {th }}$ century. ${ }^{8}$ Yet, random factors also contributed to the division between Princely States and British India; indeed, historian Robin Jeffrey has argued that there "was an awesome arbitrariness about who got a treaty and who did not" (Jeffrey 1978, p. 7).

\subsection{Religion of Princely State Rulers}

Princely States were of three broad types: antique states, successor states, and conquest states (Ramusack 2004). Antique states had long historical roots predating the arrival of the Europeans. For example, the ancient Rajput-ruled states of western India existed before the arrival of the Mughals. They survived the Mughal Empire by marrying their daughters to Mughal emperors in exchange for local autonomy (Ramusack 2004). Successor states were former provinces of the Mughal Empire that emerged as independent states when the power of the Empire declined in the $18^{\text {th }}$ century. Only one of these states, Hyderabad, survived British annexation and the other two (Bengal and Awadh) became part of British India. Most remaining states were founded in the $18^{\text {th }}$ century by mercenaries that offered military protection to local populations. The rulers in these conquest states in many cases had no historical relationship to the area or local population. In a few cases the territory

\footnotetext{
${ }^{7}$ See Iyer (2010) for more details on changes in the British annexation policy over time. The British did not annex many territories after 1857 and there were no annexations in the year of our study. Mandar and Swamy (2012) and Roy (2013) also offer details on how the East India Company became the dominant political player in this period.

${ }^{8}$ This was known as the Policy of the Ring Fence and was dominant from 1765 to 1818.
} 
under their control was also not contiguous. ${ }^{9}$

Our analysis exploits a unique and understudied feature of the Princely States: the religion of the ruler. While Hindu kings ruled most states, Muslim and Sikh rulers were not uncommon (15 and 5 percent of states in our sample, respectively). Muslim ruled states existed in every region (see Figure 1) and were not necessarily correlated with large local Muslim populations. Drawing on the Imperial Gazetteer of India (Hunter et al., 1907), Appendix Table A.1 briefly summarizes the founding of the Muslim states. Muslim ruled states were generally founded by Mughal nobles or members of the military after the death of the Mughal Emperor Aurangzeb in 1707. For example, the Muslim rulers of Balasinor, Junagadh, and Radhanpur were descendants of a distinguished Mughal officer, Sher Khan Babi, who successfully overthrew the Mughal governor above him in the $18^{\text {th }}$ century. Another example is the case of Asaf Jah, a military noble of the Mughal court who was sent by the Mughal Emperor to serve as the governor of Hyderabad province. He soon found himself strong enough to distance the province from the Mughal Empire, and he established the largest Muslim ruled Princely State over a Hindu majority population. Asaf Jah's descendants also founded the state of Baoni in central India.

Many soldiers of the Mughal army became mercenaries for the emerging Maratha leaders as the Mughal Empire weakened. In exchange they received territory in Rajasthan and central India. For example, Amir Khan, was one such mercenary who founded the state of Tonk in Rajputana. The Maratha chief Holkar Rao initially rewarded Amir Khan with this land and then the British offered him indirect rule if he gave up attacking other parts of the region. In neighboring central India, Amir Khan's brother-in-law, Gafur Khan, established the Muslim ruled state of Jaora, again supported by the Holkar. The East India Company signed a treaty with Gafur Khan in exchange for providing six hundred horses and a certain number of troops while recognizing that "his [Gafur Khan's] race being as much a foreign race in the eyes of the aboriginal inhabitants as is that of the British" (Malleson 1875, p. 221). Against this backdrop it is unsurprising that almost $50 \%$ of Muslim rulers had no strong ties to the populations that came under their rule. In comparison, $90 \%$ of non-Muslim rulers had historical links to their local populations. ${ }^{10}$

Muslim rulers also built ties with the British. In Punjab, Dujana, and Pataudi were land grants, i.e., the territory of the entire state, to loyal Muslims who worked for Lord Lake, the commander-in-chief of the British military in the early $19^{\text {th }}$ century. The Muslim rulers of Palanpur were attacked by the Marathas and sought protection from the East India

\footnotetext{
${ }^{9}$ For example, the state of Baroda included territories intermixed with districts of British India and other Princely States.

${ }^{10}$ This is based on calculations using the history in the Imperial Gazetteer (Hunter et al., 1907).
} 
Company. As these examples illustrate, many Muslim rulers were connected to their local area and population by conquest supported externally either by the Mughal Empire, the Marathas, or the East India Company. That is, while rulers were not exactly randomly assigned to a state, in many cases the religion of the ruler was not a function of the religious or economic characteristics of the population.

Once a state came under native rule, there was remarkable persistence in the religion of the ruler. The Princely States were autocracies and rulers remained in power until their death, at which point the nearest male heir (or female in the case of Bhopal) took the throne. ${ }^{11}$ If the heir was a minor, British appointed officials assisted during the transition along with state ministers. The chief ministers (diwans) appointed by the rulers played a central role managing tax collection and the general administration of the state including public services. ${ }^{12}$ Many rulers recruited non-locals for these administrative jobs. This neutralized the power of local elites and ensured that positions close to the ruler were occupied by non-locals loyal to the ruler. Rulers in the progressive southern states of Cochin, Travancore, and Mysore recruited non-Malayali, Marathi, and Tamil brahmans to serve as their chief ministers. Bengali kayasths and Kashmiri brahmans were common administrators in the northern states (Ramusack 2004). ${ }^{13}$ Interestingly, the administrators did not always share the religion of the ruler. For example, the Hindu ruler of Alwar intentionally recruited Muslim diwans who did not share any religious bonds with the local nobility (Jeffrey 1978). Broadly, this suggests that public schools did not educate state administrators and bureaucrats in this context.

In the $18^{\text {th }}$ and early $19^{\text {th }}$ centuries, both Muslim and non-Muslim states were frequently fighting each other or (more often) the East India Company. Public money largely went to support military campaigns and the provision of public goods was ignored (Roy 2013). Beginning in the mid- $19^{\text {th }}$ century, however, the situation changed. Rulers began to adopt policies from other states and neighboring British India. They promoted railways, post offices, and public schools within their domain. For example, public schooling thrived under the guidance of the Gaekwad of Baroda, a progressive Hindu ruler who introduced compulsory education more than fifteen years before a similar policy was enacted in British India.

\footnotetext{
${ }^{11}$ Mysore is an exception to this rule because it was ruled by Hindus, then taken over briefly by Haider Ali and his son Tipu Sultan, but the East India Company restored the former Hindu Wodeyar rulers to the throne after they defeated Tipu Sultan.

${ }^{12}$ Diwans appear to have played a key role in the provision of railways in some states (e.g., in Hyderabad [Ray 1984]).

${ }^{13}$ In the $20^{\text {th }}$ century, conflicts arose in many states between these 'foreign bureaucrats' and the local populations desirous of greater participation in the administration of their states. See Jeffrey (1978) for the consequences of such divides in the case of Hyderabad.
} 
A coalition of states in Bombay (Hindu and Muslim) developed a joint railway project to facilitate trade. These public services came on the scene many decades after the founding of Princely States and reflected $19^{\text {th }}$ and $20^{\text {th }}$ century priorities. Rulers of both religions were key to whether such schemes were adopted and extended. These rulers were important players in local affairs and the allocation of public goods. Our main focus is on whether the religion of the ruler had a differential impact of the provision of these services.

\section{A Simple Model of Religious Identity and Public Good Provision}

In this section, we present a simple model of religious identity and public good provision. The model provides intuition and testable predictions which guide our analysis. We stress that there are many possible mechanisms connecting the religion of a ruler to public good provision, and we highlight only one. Indeed, since most of the potential mechanisms are unobservable (including the one highlighted here) and therefore untestable, the best one can do is to flesh out the implications of the mechanism and test those implications. This is the approach that we take. It is possible - indeed, probable - that other mechanisms played a role in determining the relationship between religious identity and public good provision. But, as we show below, the mechanism that we focus on accounts for many non-obvious empirical observations.

The model solves for a partial equilibrium. We only consider the decisions made by a ruler; the "decisions" made by subjects and other political agents are left in the background. Hence, decisions are not strategic. The ruler simply maximizes his utility subject to the constraints he faces. The benefit of the model's simplicity is that it permits straight-forward comparative statics, which we test with data from the Princely States.

Consider a world with two religions, $r_{1}$ and $r_{2}$, where $r_{1}$ is the religion of the Ruler $(R)$. Fraction $\alpha \in(0,1)$ of the (non-modeled) subjects practice religion $r_{1}$, while fraction $1-\alpha$ practice $r_{2}$. $R$ has access to tax revenue $T \in \mathbb{R}^{+}$, which he splits between public good expenditure and all other expenditure. This is a simplified, reduced-form representation of the idea that rulers gain utility foremost from staying in power. In the reduced form, rulers can increase their likelihood of staying in power by spending on public goods and other types of spending. Public goods can contribute to a ruler's stability because they help reduce unrest, decrease the attractiveness of alternatives to the ruler, and increase the tax base (they also contribute to personal glory, which may enter the ruler's utility function). For the sake of the model, we are unconcerned why the ruler desires public goods, so long 
as they provide some benefit. Other types of expenditure also help keep the ruler in power: military spending, funding a bureaucracy, or buying off the elite. The ruler chooses to spend $G \in[0, T]$ on public good provision and the rest on other expenditure $(T-G)$. By its nature, the public good is not excludable, and it is therefore available to all subjects regardless of their religion.

Private markets also produce a good that is a close substitute to the public good. Unlike goods provided by the ruler, goods provided by private markets are excludable (e.g., religious education). Specifically, private markets provide $g_{i} \in \mathbb{R}^{+}$of the good to each subject of religion $r_{i}$. Assuming that all subjects consume an equal amount of the public good, the total amount of the good (and close substitute) consumed by subjects of religion $r_{1}$ is $G_{1}=\alpha G+g_{1}$, while the amount consumed by subjects of religion $r_{2}$ is $G_{2}=(1-\alpha) G+g_{2}$.

As noted above, $R$ derives utility from consumption of the good by the subjects. Assume that, all else equal, he derives more utility when subjects of his own religion consume the good than when subjects of the other religion consume the good. ${ }^{14}$ In other words, $R$ is concerned with the weighted sum of subjects' consumption, where the weight on the consumption of subjects of religion 1 is greater than that of religion 2. Denote the weighted sum as $G^{R}=\beta G_{1}+G_{2}$, where $\beta \in(1, \infty)$. $\beta$ is interpreted as the ruler's "identity preference" parameter; the greater $\beta$ is, the more that $R$ derives utility from the consumption of his co-religionists relative to those of the other religion. This is the only assumption we make in which the ruler's religious identity matters. $R$ 's optimization problem can therefore be written as: ${ }^{15}$

$$
\max _{G} U=u\left(G^{R}, T-G\right),
$$

where $u_{i}>0, u_{i i}<0, u_{12}>0$ for $i \in\{1,2\}$, and $u(\cdot)$ is well-behaved and twice-differentiable. The assumption $u_{12}>0$ indicates that providing the public good and other expenditures are complementary inputs into securing the ruler's power.

The maximization problem represented in (1) can be re-written as a function of $G$, since $G^{R}=\beta G_{1}+G_{2}=(1+\alpha(\beta-1)) G+\beta g_{1}+g_{2}$ :

$$
\max _{G} U=u\left((1+\alpha(\beta-1)) G+\beta g_{1}+g_{2}, T-G\right)
$$

It follows from the first-order condition of (2) that the optimal amount of $G$, denoted

\footnotetext{
${ }^{14}$ For the classic analysis of the manner in which identity enters into the utility function, see Akerlof and Kranton (2000).

${ }^{15}$ Formally, $\mathrm{R}$ maximizes $u(\cdot)$ subject to the constraint $G \leq T$. We assume that this constraint is not binding in equilibrium and do not consider it for the remainder of the analysis.
} 
$G^{*}$, is uniquely solved in the following equation: ${ }^{16}$

$$
\frac{u_{2}}{u_{1}}=1+\alpha(\beta-1)
$$

It is straight-forward to show that there are increasing differences in $\left\{G,-g_{1},-g_{2}\right\}$. This is unsurprising, since a greater level of private good provision makes public good provision less valuable on the margin. It thus follows from monotone comparative statics (Milgrom and Shannon 1994; Topkis 1998) that the equilibrium level of public good provision, $G^{*}$, is decreasing in the level of private good provision of either religion $\left(g_{1}\right.$ or $\left.g_{2}\right)$. It is also straight-forward to show, using the Implicit Function Theorem, that $\frac{\partial G^{*}}{\partial g_{1}}=\beta \frac{\partial G^{*}}{\partial g_{2}}$. This is also unsurprising, as $R$ derives a multiple of $\beta$ more marginal utility from $g_{1}$ than from $g_{2}$ (i.e., $\frac{\partial U}{\partial g_{1}}=\beta u_{1}, \frac{\partial U}{\partial g_{2}}=u_{1}$ ).

In other words, the amount of public good provision is decreasing in the level of private good provision, and the magnitude of the decrease is greater when the private good is provided to subjects of the same religion as the ruler. The intuition underlying this result is straight-forward. Since the ruler cares more about the consumption of subjects of his religion (i.e., $\beta>1$ ), an increase in $g_{1}$ reduces the marginal gain in utility from increasing $G$ by more than a similar increase in $g_{2}$ (since $R$ 's utility is subject to diminishing marginal returns). An increase in $g_{1}$ also increases the marginal gain from the ruler's consumption (i.e., $T-G$ ) more than a similar increase in $g_{2}$, since the ruler's consumption and the consumption of the public good are complements. This result is summarized in Proposition 1:

Proposition 1 (Private Good Effect): The level of public good provision is decreasing in the level of private good provision, ceteris paribus, and the magnitude of this effect is greater for private good provision targeted at subjects of the ruler's religion.

Next, consider how the population share of the ruler's co-religionists, $\alpha$, affects public good provision. Increasing $\alpha$ has two countervailing effects. One effect is that it increases the multiplier associated with $G^{R}$. Since the ruler is more concerned with the amount of the public good consumed by his co-religionists, he benefits more from higher $G$ when $\alpha$ is large. On the contrary, as $\alpha$ increases, diminishing returns kick in, thereby reducing the attractiveness of increasing $G$. Hence, $\frac{\partial G^{*}}{\partial \alpha}$ is either negative or positive, depending on which effect is stronger. In order to derive a comparative static result that sheds light on the case of the Princely States, we assume that $G^{*}$ is relatively small and hence marginal

\footnotetext{
${ }^{16}$ It is straightforward to see that the second-order condition holds, as $(1+\alpha(\beta-1))^{2} u_{11}-$ $2(1+\alpha(\beta-1)) u_{12}+u_{22}<0$.
} 
returns are minimally diminishing. ${ }^{17}$ Under these conditions, the former effect dominates and $G^{*}$ is increasing in $\alpha$. This result is summarized in Proposition 2:

Proposition 2 (Population Share Effect): When $G$ is sufficiently small, the level of public good provision is increasing in the share of the population that are co-religionists with the ruler, ceteris paribus.

\section{Testable Predictions in Historical Context}

The model highlights two avenues through which a ruler's identity can affect public good provision: the Private Good Effect and the Population Share Effect. The former effect arises when a close substitute of the public good is provided by private markets. If it is provided more to the ruler's co-religionists by private markets, the ruler will provide less of the public good, since it is less valuable on the margin to his co-religionists. The Population Share Effect simply indicates that rulers provide more of a public good when there is a greater share of their co-religionists in the population.

These two effects are not mutually exclusive, although it is an inherently empirical question as to whether either or both arises in the real world. The strength of both effects is dependent on the shape of the ruler's utility function. If either effect enters weakly into the ruler's utility function, statistically and economically insignificant results will follow.

In this section, we discuss the testable implications of the model for the Indian Princely States in the early $20^{\text {th }}$ century. As we describe in the next section, we have collected data on religion-specific literacy (for Hindus and Muslims) in 1911 and 1931, the number of public schools and enrollment in these schools as of 1904, 1911 railway provision, and 1911 post office provision for the Princely States. These variables provide a nice test of the model's predictions, since the model predicts that they should be affected in different ways by the religious identity of the ruler.

First, consider the effect that ruler identity has on literacy (via investment in schools). There were three types of schools in the Princely States: public schools supported by the state, religious schools (of which Muslim maktabs and madrasas were more common than Hindu schools), and private schools maintained by local landlords or Christian missions. The ruler was instrumental in the provision of public schools that were the most widespread. Demand for schooling was weak in the local population, and public schools were free in many

\footnotetext{
${ }^{17}$ Formally, $\frac{\partial G^{*}}{\partial \alpha}>0$ if $u_{1}+(1+(\beta-1) \alpha) G u_{11}-G u_{12}>0$. This is clearly positive as $G \rightarrow 0$ unless $u_{111}$ or $u_{112}$ have odd properties. We do not wish to speculate on the sign or magnitude of third derivatives, and instead focus only on the part of the parameter space where a clean comparative static result arises.
} 
if not most states. Muslims were more likely to attend religious schools, while Hindus were more likely to attend public or missionary schools. ${ }^{18}$ Christian missions were less common in the Princely States compared to British India. In the context of the model, the fact that Muslims were more likely to go to religious schools meant that a close substitute for public education expenditures was provided on a proportionately greater basis to Muslims than to Hindus.

Unlike education, railways and post offices in the Princely States were supported by the state and not provided by the private sector (i.e., $g_{1}=g_{2}=0$ ). Moreover, they were both non-excludable. The first Indian railways were constructed in British India in the 1850s by private British companies under the supervision of the colonial GOI. Few of these initial lines passed through Princely State territory. Beginning in the 1870s, the Government of India sanctioned new lines passing through the Rajputana States but retained ownership of the lines. The Princely States had no decision making authority over GOI owned lines in their territory. Hyderabad was among the first Princely States to undertake direct railway construction. The Nizam (Muslim ruler of Hyderabad) provided the land free of cost to a private company to build the line, which opened in 1874. Subsequent operations were initially managed by the State and then by a private company, His Highness the Nizam's Guaranteed State Railway Company. The company was offered similar terms as other private railway companies in British India. Other states such as Baroda, Mysore, Travancore, and Cochin followed shortly. By 1911, 37 Princely States owned some type of railway.

In many cases, the construction and operation of the railways was undertaken by British companies operating railways in neighboring regions of British India. Princely States provided free land and capital for these railways. The GOI was often party to the negotiations between the states and companies. In a few cases, a group of states jointly financed the construction and operation of railways through their territories. For example, the Bhavnagar-

\footnotetext{
${ }^{18}$ Official education reports of this period often include a chapter on Muslim education, which highlight the difficulties of expanding basic education in Muslim communities because of their emphasis on religious instruction at an early age. Based on first hand accounts of districts in British India, the report says "In the case of a young Muhammadan, the teaching of the mosque must precede the lessons of the school. He enters school later than the Hindu. He must commonly pass some years in going through a course of sacred learning before he is allowed to turn his thoughts to secular instruction. The years which the young Hindu gives to English and mathematics in a public school, the young Muhammadan devotes in a madrasa to Arabic and the law and theology of Islam" (Government of India 1914, p. 245). If anything, such patterns were probably more stark in the Princely States since education systems were less developed than in British India. Princely State rulers also differed in their promotion of education based on their religion. For example, rulers of Hindu states such as Baroda and Kolhapur contributed heavily to the Deccan education society (a regional society) in the late $19^{t h}$ and early $20^{t h}$ century, and other Muslim rulers supported efforts to promote a pan-Indian version of Islam among Muslims (Ramusack 2004). Iyer et al. (2014) provide evidence from contemporary India that Muslims are still much more likely than Hindus to send their children to private religious schools.
} 
Gondal railway was a collaboration between Hindu and Muslim ruled Princely States in western India.

In theory and practice, railways were non-excludable by religion. ${ }^{19}$ Any individual with the money to buy a ticket could ride on the train. In principle, rulers could have placed stations strategically to benefit their co-religionists, but the discussion of religion never appears anywhere in the qualitative evidence on railways. In our analysis, we construct an indicator for whether a state had an ownership stake in a railway. This involved explicitly pledging capital to the line. For the set of Princely railways, we also test for differences in capital, mileage, gauge and operations between Muslim and non-Muslim states.

A uniform postal system was first created by the East India Company within its Indian territories at the end of the $18^{\text {th }}$ century. ${ }^{20}$ The system initially only allowed for public correspondence, but was soon opened to private communications for a small postage fee. In the 1830s, the British abolished all private posts and created a public Imperial Post to manage both public and private communications. As the Imperial Post was expanding in British India, many Princely States began to develop their own postal systems and individual postage stamps. ${ }^{21}$ However, the GOI soon felt the need for a uniform postal network extending to the Princely States. The first joint ventures between the GOI and various Princely States allowed for the "mutual exchange of correspondence" (Clarke 1921, p. 114). But, in the final form the Imperial Post took over the native postal service beginning with the state of Mysore in 1887. Such takeovers were conditional on the consent of the Princely ruler and his court. By the 1920s, a majority of the post offices in the Princely States were under the Imperial Post. The notable exceptions were the states of Hyderabad, Gwalior, Jaipur, Patiala, and Travancore, who continued to manage their own post offices. Again, we observe no religious pattern. Gwalior, Jaipur and Travancore were ruled by Hindus, Hyderabad by a Muslim, and Patiala by a Sikh ruler.

Similar to railways, the history of postal services suggests there were no private substitutes to the Imperial or Princely State post by the late 1800s. Both public and private correspondence was transported by them. Moreover, the provision of postal services was at

\footnotetext{
${ }^{19}$ This is also true for many districts of British India. See Bogart and Chaudhary (2012) for a background on Indian railways.

${ }^{20}$ In earlier periods runners and couriers carried state correspondence. The postal system primarily served the political needs of the state. The sparse evidence on private correspondence suggests couriers belonging to specific castes transported private correspondence for a fee (Sood 2009). A detailed economic history of the Indian post still remains to be written, but Bharat (2012) offers a first step towards understanding the spread of the postal system in the colonial period.

${ }^{21}$ Before the Imperial Post, there was no proper postal system in the Princely States except for the states of Cochin, Travancore, and Mysore where state supported local posts had a long history dating to the $17^{\text {th }}$ century (Clarke 1921).
} 
the discretion of the ruler and his court, be it to allow the Imperial Post in the state or to directly manage the postal network. The development of post offices was also not directly related to literacy. Letters were written on behalf of others and read aloud when recipients could not read. For example, according to Clark (1921), "It must not be supposed, however, that the Post Office confines its energies to the literate population. It is largely used by people who can neither read nor write, and this is made possible by the existence of professional letter-writers, who are to be found in every town and village in the country. For a pice (farthing) they will write an address, and for two pice they will write a short letter or a postcard or fill up a money order, though slightly higher fees are charged if the letter is long" (p. 94). In our analysis, we construct an indicator variable for whether a Princely State had one or more post offices. We do not focus on whether the post office came under the Imperial Post or the state because both required the approval of the ruler. ${ }^{22}$

These histories suggest that Propositions 1 and 2 can be re-worded to formulate the following testable predictions:

Prediction 1A (Private Good Effect on Literacy and Public Schools): Muslim rule should have had a negative effect on public schools, public school enrollment, and Hindu literacy but not on Muslim literacy, since Muslim religious institutions provided a close substitute to public education.

Prediction 1B: (Private Good Effect on Railways and Post Offices): The religious identity of the ruler should have had no effect on the presence of railways or post offices, since neither was provided by the private sector.

Prediction 2 (Population Share Effect): Muslim rule should have had a positive effect on Muslim literacy, Hindu literacy, public schools, public school enrollment, and the presence of railways and post offices where the Muslim population share was greater.

\section{Data}

To test the predictions of the model, we collected data on the socio-economic characteristics of the Princely States from official publications, individual histories of the State recorded in the Imperial Gazetteer (Hunter et al., 1907) and secondary sources for the early $20^{\text {th }}$ century. Although there were over 600 Princely States in 1911, many were very small, consisting of a few villages. The Indian census does not report individual data for smaller states, choosing instead to group these states and jointly report the information for a larger aggregate

\footnotetext{
${ }^{22}$ The data also do not distinguish between the different types of post offices in the Princely States.
} 
unit. These smaller states with no individual data enjoyed less autonomy than their larger neighbors and often came under the administrative oversight of neighboring British Indian provinces. Thus, they were different from the states whose data were consistently reported across the different sources. Our study focuses on 117 Princely States for which individual data are uniformly reported in the census. ${ }^{23}$ These states account for almost 80 percent of the population and 68 percent of the area covered by the Princely States. ${ }^{24} 18$ of the 117 states in our data set were ruled by Muslims.

We extracted information on total population, area in square miles, number of towns and literates for each state in our sample from the 1911 Census of India (Government of India, 1911). We chose 1911 as our year of analysis because a systematic enumeration of literacy first began with the 1911 census. Although literacy was recorded in prior censuses, it was measured in an inconsistent manner across regions. Moreover, the census claims there was often an over-enumeration of literates in these earlier censuses. Beginning in 1911, the census adopted a universal definition: any individual with the ability to read and write in any language was counted as literate. An individual who could read a religious text but who was unable to write was not counted as literate. Official discussions suggest the information collected was of good quality.

Our model distinguishes between public goods that differ along religious lines, so in our analysis we focus on Hindu and Muslim specific literacy. Since religion-specific literacy was unreported in many Princely States of central and western India in 1911 (Central India Agency States and Bombay States, respectively), we relied on information in 1901 and 1921 to construct estimates for 1911. For the Princely States of central India, we combined the 1901 Hindu and Muslim literacy rate in each state with the growth rate of Hindu and Muslim literacy between 1901 and 1911 for larger administrative units to create an estimate of 1911 literacy. In a similar manner, we combined 1921 literacy with the growth rate between 1911 and 1921 to generate estimates of 1911 literacy for the Princely States in western India. ${ }^{25}$ Since these imputations may present biases based on unobservables, we also collected data for Hindu and Muslim literacy in 1931. The 1931 census includes religion specific literacy for a larger set of Princely States and hence there are no concerns of imputation.

\footnotetext{
${ }^{23}$ We focus on a Princely State as our unit of observation. For some of the bigger states, the census reports data for administrative units below the State. But we choose not to use these data because the variation of the ruler is at the state level.

${ }^{24}$ This calculation excludes the states and agencies in the North-West Frontier Province (in present day Pakistan).

${ }^{25}$ In some cases, literacy was only reported for a small group of states in those years, in which case we assigned each state within the group the same value. These calculations are not without problems. There is strong evidence of over-enumeration in the 1901 census and the influenza epidemic occurred in 1917 raising concerns about the 1911-1921 calculation for the western Indian states.
} 
We also used the census to construct measures of the population share of Hindus, Muslims, and other religious groups (an aggregated category including Buddhists, Jains, Parsis, Sikhs, and tribal groups). Using the Atlas Map of India (Census of India 2011), we constructed a dummy for coastal states. Most Princely States were located in the interior of the country because of the nature of direct colonial expansion along the coast, but a few states in western India bordered the coast.

To capture institutional features of Princely States, we read their individual histories in the Imperial Gazetteer and created four variables. First, we recorded an indicator variable for whether the ruler or his family at the time of the state's founding was connected to the local population. This was based on our reading of the history and may be subject to some error. Larger states are described in more detail in the Imperial Gazetteer and were easier to code in general. We only coded rulers as having no historical tie if the history unambiguously indicated that the founding family was non-local to the state population. ${ }^{26}$ Second, we created an indicator variable for states that were reprimanded by the GOI for mis-management of their public finances or if they experienced an intervention by the GOI in their local affairs. Our reading suggests the GOI was more likely to reprimand or intervene in larger and more important states. It could be that the Imperial Gazetteer did not record such interventions for smaller states, but our sense is the British were generally more concerned about the bigger states.

The Gazetteer also records the number of public schools and enrollment or average daily attendance in these schools for many states as of 1903-04. In few cases the history only notes the number of schools, or the number of pupils. We extracted the information on public, i.e., state run schools and students, or those receiving subsidies from the state. In general the histories suggest many schools were supported by the state. If private schools were significant in the state, the history also described the provision of private schooling. However, it is unclear if Muslim religious schools connected to mosques are counted in the enumeration of private schools. Our reading suggests they are not always counted. Unlike British India, private schools were less common in the Princely States and they seemed to have a presence in larger states such as Baroda, Cochin, Hyderabad, Mysore, and Travancore. Other than the Imperial Gazetteer, we are unaware of any historical sources with schooling data for a large sample of Princely States.

To measure the provision of railways, we used the 1911 Administration Report on Rail-

\footnotetext{
${ }^{26}$ This coding creates problems for Maratha successor states such as Indore, Gwalior and Baroda. We chose to code these states as having no historical ties because they represent successor states of the Maratha Empire at the time of founding although clearly by the early 20th century their rulers would be viewed as strongly tied to the population. We did this to be consistent across Hindu and Muslim states in the coding.
} 
ways. Based on the history of each railway, we constructed an indicator for railway ownership. We coded this variable as one only if a Princely State explicitly owned any portion of a railway line passing through its territory. States with railways that were wholly owned by the GOI or a private company were coded as zero. We also collected information on total mileage, capital expenditures, gauge, and operations. The post office data are from the annual Post Office Guide for 1911. Again, we created an indicator for whether a state had one or more post offices in their territory. ${ }^{27}$

We coded the religion of the Princely State ruler using Iyer (2010). For states that were unreported in Iyer (2010), we used The Native States of India (Chakrabarti 1895). The religion of the ruler in the latter publication is reported as of 1890, but there is no significant variation in this variable over time. In general, members of the same family ruled these states for decades. We also used The Native States of India to collect information on tax revenues as of 1890 and the number of gun salutes received by the ruler.

We coded the year the state was founded using individual state histories described on an online website. ${ }^{28}$ Using this information, we constructed an indicator for whether the state was founded prior to or after the end of Aurangzeb's reign in 1707, which is commonly viewed as the beginning of the decline of the Mughal Empire. States that emerged in the aftermath of the decline of Mughal rule may have differed from older states for many reasons. Older states may have had enduring institutional structures in place and were perhaps less likely to adopt the institutional practices of the Mughal Empire. It is also possible these states were more economically and politically powerful than states founded in the wake of Mughal collapse.

The decline of Mughal rule may have also independently influenced the trajectory of economic development in the Princely States. For example, areas where Mughal rule declined earlier may have weaker Muslim religious authorities and less emphasis on religious instruction for Muslims. This could be independent of subsequent Muslim rule in the region. Many areas that went on to become independent Princely States were under Mughal rule in the $16^{\text {th }}$ and $17^{\text {th }}$ century. To capture the decline of Mughal rule, we coded states based on whether Mughal rule declined before 1765, between 1765 and 1805, and after 1805 .

\footnotetext{
${ }^{27}$ Sheetal Bharat generously shared her data on post office provision that was compiled using the Post Office Guide (Bharat 2012). We used these data to construct our measure. Although the data are detailed enough to allow a count of the number of post offices in each state, we are hesitant to use this intensive measure because the data sources are unclear whether they encompass all the post offices in each Princely State.

${ }^{28}$ This website (princelystatesofindia.com) was recently taken down. In our analysis, we only use a dummy for whether the state was founded pre- or post-1707. This information is easy to verify in the Imperial Gazetteer of India (Hunter et al., 1907).
} 
Following the Battle of Plassey, Bengal and Bihar came under the rule of the East India Company. Mughal rule also collapsed in the northern and eastern parts of India before 1765 as large areas came under the rule of the Marathas. In the next wave, Mughal rule collapsed in Madras, Orissa, Punjab, and the United Provinces. While most of these territories went to the East India Company, some went on to become Sikh Princely States in the north. This information is coded based on a map in Robinson (1982). As seen in the map, there is limited variation in these indicators for Princely States within the same region unlike for British India (figure 2).

Given the historical variation within Princely States, we believe focusing on local comparisons is very important. Comparing the Muslim state of Hyderabad in peninsula India to the northern Hindu state of Jammu and Kashmir is an apples to oranges comparison. Hence, we code six regions of the Princely States. These are the Rajputana States in northwest; the Punjab States plus Jammu and Kashmir in the north; the Central India Agency States; Bombay and Western India Agency states in the west; Rampur and Tehri Garhwal in the United Provinces; Cochin, Travancore, Mysore, Hyderabad and two smaller states in the south; and finally the states of Cooch Behar, Hill Tipperah and Manipur in the east.

Table 1 presents summary statistics by religion of the ruler (Muslim and non-Muslim). There are no statistically significant differences in the means of the dependent variables of interest (Hindu and Muslim literacy, schools, railways and post offices) between Muslim ruled and non-Muslim ruled states. Muslim-ruled states were more likely to be coastal because of the Muslim-ruled states in western India bordering the sea (see Figure 1). They were also more likely to be founded during the decline of the Mughal Empire (after 1707) and have fewer rulers with historical ties to the state at the time of founding. There are no significant differences in the number of gun salutes or intervention by the colonial government. There were more Muslims on average in Muslim-ruled states: the Muslim population averaged 22\% in Muslim-ruled states versus $9 \%$ in non-Muslim states. These averages mask incredible heterogeneity across states. For example, Muslim-ruled states such as Hyderabad (10.3\%) and Bhopal (11.2\%) had relatively small Muslim populations compared to Malerkotla (36.5\%) or Rampur (46.0\%). Likewise, non-Muslim ruled states varied from very low Muslim populations in Tehri Garhwal (0.6\%) and Rewah (2.2\%) to large Muslim populations in Jammu and Kashmir (75.5\%) and Cooch Behar (30.8\%). 


\section{Identifying the Effects of Muslim Rule}

The theoretical model illustrates how Muslim rule may affect public good provision. First, if the public good in question is also provided by the private sector, then Muslim rule directly effects public good provision, with the direction of the effect depending on the degree to which Muslims benefit from the private good (Private Good Effect). Second, Muslim rule may have a positive effect on public good provision in states with a larger share of Muslims (Population Share Effect).

We use the provision of public goods and literacy to test the predictions of the model. We estimate a cross-sectional regression for each Princely State $i$ in region $j$. Our dependent variables are the Muslim literacy rate, Hindu literacy rate, the number of public schools, school enrollment, an indicator for railway provision, and an indicator for post office provision. The primary independent variables of concern are an indicator variable for whether the state had a Muslim ruler and the interaction of this variable with the Muslim population share. Thus, our estimating equation takes the following reduced form:

$$
y_{i j}=\alpha+\beta_{1} \text { MuslimRuler }_{i j}+\beta_{2} \text { MuslimRuler }_{i j} * \text { FractionMuslim }_{i j}+\gamma X_{i j}+\delta_{j}+\varepsilon_{i j}
$$

The vector $X_{i j}$ includes characteristics of Princely States that may jointly influence the

religion of the ruler and public goods. These include the number of towns divided by area (a proxy for urbanization), an indicator for coastal districts, the log of state revenues divided by area (primarily land tax revenues), the area of the state, Muslim population share, and the population share of other religions (non-Hindu and non-Muslim). In the case of schools and pupils, we cannot include towns or the religious population shares because they are measured as of 1911 while the schooling data is for 1903-04.

We also explore the effects of institutional variables; namely, whether the state was founded after the decline of Mughal rule (in 1707); the number of gun salutes recevied by the state (a measure of their importance to the GOI); whether the founding family of the state had strong historical ties to the region; whether the state was reprimanded or faced an intervention by the GOI; and indicators for the differential decline of Mughal rule. We include region fixed effects captured by $\delta_{j}$ in all the regressions so that we focus on local comparisons. There is sufficient variation in the data to include region fixed effects because Muslim-ruled states were spread all over India (see Figure 1).

The main econometric challenge in this set up is the differential selection of Princely States to Muslim rule. As noted earlier, many Muslim-ruled states emerged in the aftermath of the decline of the Mughal Empire and were ruled by former members of the Mughal army 
or nobility. Muslim rulers were not always related to the local population and in some cases received the land that they went on to rule from the Marathas (Hindus). This suggests an element of randomness in the assignment of Muslim rule. Yet, selection concerns still remain. To address the possibility of differential selection, we rely on matching techniques using inverse probability matching weights. The idea underlying matching is an apples-toapples comparison by using similar treatment and control groups to generate an estimate of the treatment effect. ${ }^{29}$

In our context, the treatment is the religion of the ruler, i.e., Muslim ruler and the control is non-Muslim ruler. We use the following key observable variables to generate comparable groups of Muslim and non-Muslim ruled states: the area of the state, an indicator for coastal location, an indicator for whether the state was founded after 1707 (Aurangzeb's death), and region fixed effects. By giving more weight to observationally similar treatment and control groups, the matching estimator provides a cleaner measure of the treatment of Muslim rule, provided no significant unobservable factors are driving selection into Muslim rule. Ideally, we want to compare the state under Muslim rule to the same state under Hindu rule. Since this is not feasible in our context, matching offers the next best alternative by comparing states under Muslim rule to states under Hindu rule that share similar observable characteristics.

To generate matching estimates, we rely on the inverse probability matching technique. ${ }^{30}$ Most matching estimations compare outcomes for matched treatment and control groups, rather than test for differential effects of treatment. We follow this approach and restrict the matching analysis to comparisons of our key outcome variables between Muslim and non-Muslim ruled states. We do not test for differential effects using matching, which is non-standard using these techniques. To implement matching we run a first stage regression with Muslim Ruler as a dependent variable on an indicator for coastal states, area of the state, indicator for post-1707 founding and region fixed effects. We predict the residual and generate weights based on the residual. These inverse probability weights are defined as $1 /$ residual for Muslim ruled states, and 1/(1-residual) for non-Muslim ruled states. In the second stage we use the inverse probability weights to run a weighted (i.e., matched) OLS regression.

The institutional setup has to satisfy two assumptions for matching to be a valid estima-

\footnotetext{
${ }^{29}$ Matching estimates are commonly used in the program evaluation literature. Participants are assigned to a treatment (e.g., a job training program). Their wage or other outcomes after program participation are compared to a matched group of similar non participants to generate the causal effect of the treatment. Imbens and Rubin (2015) provide an overview of matching methods.

${ }^{30}$ Our results are robust to other propensity score techniques such as nearest neighbor matching.
} 
tion strategy. First, there needs to be a sufficiently large group of Hindu states that share similar observables to Muslim states (the common support assumption). This assumption is valid in our context because we observe both Hindu and Muslim ruled states of comparable area, adjoining the coast, founded after 1707, and situated in the same region. Figures 3 and 4 both show the areas of overlap between the Muslim and non-Muslim states using histograms and kernel density graphs of our first stage residuals. If the two graphs did not overlap in Figure 4, it would suggest we had insufficient common support to identify the impact of Muslim rulers.

Second, we assume in such a matching set-up that selection into Muslim rule is primarily driven by observable factors. One justification for this assumption is that many conquest states were established by Hindu and Muslim mercenaries after 1707 in western and central India. After accounting for size, post-1707 founding (i.e., conquest state), region, and proximity to the coast, any unobservable factors influencing Muslim rule are probably of small magnitude and unlikely to bias the coefficients in a significant manner. Matching provides an alternate estimate of Muslim rule, one that is more robust to selection bias compared to the cross-sectional OLS estimates.

\section{Results}

We report results on literacy in 1911 and 1931 in Tables 2 and 3. Columns 1-3 suggest there was a negative but insignificant impact of Muslim rulers on total literacy in 1911. The signs on the socio-economic variables are as we would expect. More urbanized states near the coast have higher literacy. Younger states have lower literacy (Founded Post-1707), while the number of gun salutes has a positive impact.

The more interesting results emerge when look at religion-specific literacy. We find the coefficient on Muslim Ruler $\left(\beta_{1}\right)$ is negative and statistically significant in the Hindu literacy regressions but not in the Muslim literacy regression. This result lends support to the saliency of the Private Goods Effect. Average Hindu literacy in states with Muslim rulers is 2.3 percentage points lower than in states with non-Muslim rulers. This is far from a trivial difference, as Hindu literacy averaged only 4.3 percent in the Princely States. Columns 5 and 7 include the interaction between Muslim Ruler and Fraction Muslim $\left(\beta_{2}\right)$, allowing us to test the saliency of the Population Share Effect. The coefficient on the interaction is positive but statistically insignificant. Meanwhile, the coefficient on Muslim Ruler $\left(\beta_{1}\right)$ remains large, negative, and statistically significant in the Hindu literacy regression but not the Muslim literacy regression where the coefficient is smaller in magnitude and statistically 
insignificant. ${ }^{31}$ Most of the institutional variables are small in magnitude and insignificant, possibly due to limited variation in these variables within regions.

Table 3 presents the results for Hindu and Muslim literacy in 1931. The results on Muslim ruler are remarkably similar after controlling for differences between states. Hindu literacy is 2.8 percentage points lower in states with Muslim rulers (Column 3). Since Hindu literacy increased during this period, the economic significance of the coefficient is slightly smaller than in 1911. Again, we find no significant effect of Muslim ruler on Muslim literacy (columns 4-6). The 1931 results indicate that our findings on Muslim ruler in Table 2 are not driven by data imputations for 1911 religion-specific literacy. In terms of our model, the results support the saliency of the Private Goods Effect but only weakly support the saliency of the Population Share Effect.

We explore the impact of Muslim rulers on public schools and enrollment in Table 4. Our sample size decreases slightly in these regressions because the information was not consistently reported in the Imperial Gazetteer. In principle the number of schools and enrollment should be standardized by population but our population data is for 1911 while our education data is of $1903 / 04$. Hence, we choose to report the results for the number of schools and pupils. ${ }^{32}$ Our results are not precisely estimated for schools, but they confirm a negative impact of Muslim ruler on the number of public schools. We also observe a negative and statistically significant impact of Muslim ruler on enrollment. Since Muslim ruled states were larger on average, this finding on enrollment in not capturing differences in the area and population between the two types of states. Overall, the findings on schools and pupils support the idea that Muslim ruled Princely States had less public schooling.

Although the results highlight the negative impact of Muslim rulers on education, one may be concerned that Muslim ruled states were poorer on average with less money to support public education. This is unlikely because the revenue per area was higher for Muslim ruled states, but it could be that revenues in this context are an imperfect proxy for income. In Table 5 we study the provision of post offices and railways. These public goods provide an additional test for income differences. Railways in particular were an expensive infrastructure investment. States without the resources were unlikely to embark on a program of railway development. As expected in Table 5 we find that revenues are a significant determinant of whether Princely States invested in railways as are the number

\footnotetext{
${ }^{31}$ The results are robust to using weighted OLS (weighted by population), dropping outlier states (in terms of population), and including an additional control to capture religious fragmentation in the state.

${ }^{32}$ Our results are similar if we use the 1911 population but since that is not the correct way to standardize we choose not to report those results. The 1901 Census does not report population for the same set of states as the 1911 Census.
} 
of gun salutes, another measure of the stature of the state. We find no significant impact of Muslim ruler $\left(\beta_{1}\right)$ on railways or post offices. The coefficient is positive but insignificant for post offices, and negative and insignificant for railways. This suggests again that income differences between Muslim and non-Muslim ruled states are not driving our results. Overall, the results in Table 5 indicate that we cannot reject the hypothesis that the Private Goods Effect is salient, as it predicts that the ruler's identity should have no effect on the provision of pure public goods that are not provided by the private sector. In Columns 3 and 6 of Table 5, we report regressions with the interaction term $\left(\beta_{2}\right)$ in order to test the Population Share Effect. This coefficient is statistically insignificant across both specifications.

Owning a railway is a crude measure of provision because railways differed on many dimensions such as gauge and operations. We use information reported in the 1911 Administration Report on Railways to test for differences between Muslim and Non-Muslim states on other railway metrics. Table 6 presents the results. Indian Railways were built on a standard, 5 feet 6 inch gauge, a meter gauge of 3 feet $3 \frac{3}{8}$ inch, or a narrow gauge of around 2 feet. Standard gauge railways were the most expensive but could also transport heavier wagons and traffic. We observe no significant differences in total mileage or mileage under specific gauges between Muslim and non-Muslim states. In fact, average total mileage is remarkably similar at 111 miles for Muslim rulers and 117 for non-Muslim rulers. Capital per mile is higher on average in Muslim ruled states but the difference is insignificant. On the operations side, we observe no statistically significant differences by the religion of the ruler on whether railways were operated by the GOI, a private company, or Princely State.

Given the potential selection bias of Muslim Rulers, we present results using inverse probability matching in Table 7. These estimates support the findings of our cross-sectional regressions. The estimates on 1911 and 1931 Muslim literacy and railways are all statistically insignificant, while the estimate of Muslim Ruler $\left(\beta_{1}\right)$ on 1911 and 1931 Hindu literacy is negative, and statistically significant. The magnitude of the coefficients on Muslim Ruler are remarkably similar for 1911 and 1931 at 2.9 percentage points and 3.0 percentage points respectively. Interestingly we find a large and positive impact of Muslim rulers on the provision of post offices in these matched comparisons. We are uncertain as to what is driving this result, but it does suggest public good provision was not universally lower in Muslim-ruled states. As in the OLS regressions, the findings on schools and pupils are negative in Table 7 , but insignificant.

In sum, these results provide strong evidence in support of the Private Goods Effect, but very weak support for the Population Share Effect. We recognize there could be other explanations for these results. The first explanation that comes to mind is one of patronage. 
Muslims were less likely to support public education for Hindus because there was no direct fiscal benefit to them of extending such education. Income taxes were low if not absent in most Princely States and rulers could not recuperate fiscal investments in schools. In contrast, rulers may have invested in the education of their co-religionists if they were more likely to hire administrators and ministers from this group. This simple patronage story would suggest a negative impact of Muslim rulers on Hindu literacy and a positive impact on Muslim literacy. However, we only find a negative impact on Hindu literacy. More importantly, administrators in many states were outsiders and did not share the religion of the ruler. According to historian Barbara Ramusack (2004), the two most common groups of princely state administrators in the northern states were English-educated Bengalis and Kashmiri brahman pandits: "Western-educated Bengalis, generally bhadralok or respectable people and more particularly kayasthas had followed British armies and administrators into newly annexed areas of Punjab, Awadh and Rajput states" (p. 183). Similarly, the Kashmiri pandits fluent in both Persian and English were prominent in Patiala, Indore and Gwalior. Such outside ministers were actively encouraged by the British (Ramusack 2004). As mentioned earlier there was no strong religious element to administrator either. Against this backdrop we believe our findings are not a function of pure state patronage to support public administration.

Another explanation, not mutually exclusive from our theoretical mechanism, relates to selection into Islam. It could be the case that non-Muslims were more likely to convert to Islam in Muslim ruled states to court favor and patronage. Again, it is unclear what form this favor and patronage took because public services such as railways and post offices were available to all religions. More importantly, if there was positive selection into Islam we would expect both a positive coefficient on Muslim literacy and a negative coefficient on Hindu literacy. According to discussions on religion in the Census of India, forced conversions were not common in the $19^{\text {th }}$ and $20^{\text {th }}$ century as compared to centuries past before the arrival of the British. They also suggest more converts to Islam in this time were from the lowest Hindu castes. In this discussion about western India, the Census had the following to say:

Along the coast the religion was brought by traders from Arabia and Persia, in Gujarat and the Deccan, as far south as Bijapur, by invading armies from Delhi, and in the extreme south of the Presidency many Jains were forcibly converted by Haidar Ali and Tipu Sultan. In Sind the aboriginal tribes became Muhammadan from the time of Arab conquest and under the rule of the Kalhora and Talpur Kings. Now the age of compulsory conversions is over and the proselytizing zeal 
of Islam a thing of the past; though the religion of Muhammad still obtains converts they are a neglible number and drawn from the lowest Hindu castes, who seek thereby to improve their social status (Census of India 1911, p. 68).

While we cannot quantitatively rule out these competing explanations, we believe our hypothesis is an important link from Muslim rulers to Hindu literacy for two reasons. First, it is derived using a straight-forward model with minimal and standard assumptions on human behavior. Second, it explains why ruler identity matters in some contexts (i.e., when substitute goods are privately provided) but not others. An alternative hypothesis would have to explain why Muslim rule is bad for Hindu literacy but not bad (or good) for other types of public good provision.

\section{Conclusion}

This paper provides a theory of how a ruler's religious identity affects the provision of public goods. A simple model suggests that there are two possible causal pathways. First, a ruler may provide more public goods when a greater portion of his subjects are co-religionists. Second, rulers may provide less of a public good if the private sector provides his co-religionists with a substitute good that is excludable by religion (e.g., religious education).

In order to test these hypotheses, we exploit a newly constructed data set on the Indian Princely States for the early $20^{\text {th }}$ century. Using data on religion-specific literacy, schools, school enrollment, railway ownership, and post office provision, we find support for the second, but not the first, of these hypotheses. In particular, we find that Hindu literacy, schools, and enrollment - but not Muslim literacy, railway ownership, or post office provision - are negatively affected by the presence of Muslim rule. This result is consistent with our hypothesis, since private Muslim schools were prevalent and it follows that Muslim rulers would have less incentive to spend money on public primary education.

These results suggest that there is nothing about religious doctrine per se that affects public good provision. This insight provides a twist on the Weberian connection between religion and economic outcomes. It suggests that while the role of doctrine should not necessarily be ignored, religious identity can play an important role in affecting economic outcomes regardless of the content of religion. 


\section{References}

1. Akerlof, George A., and Rachel E. Kranton. 2000. "Economics and Identity." Quarterly Journal of Economics 115(3): 715-753.

2. Arruñada, Benito. 2010. "Protestants and Catholics: Similar Work Ethic, Different Social Ethic." Economic Journal 120(547): 890-918.

3. Barro, Robert, and Rachel M. McCleary. 2003. "Religion and Economic Growth Across Countries." American Sociological Review 68(5): 760-781.

4. Becker, Sascha O., and Ludger Woessmann. 2009. "Was Weber wrong? A human capital theory of protestant economic history." Quarterly Journal of Economics 124(2): $531-596$.

5. Berman, Eli. 2000. "Sect, subsidy, and sacrifice: an economist's view of ultra-orthodox Jews." Quarterly Journal of Economics 115(3): 905-953.

6. Bhalotra, Sonia, Irma Clots-Figueras and Lakshmi Iyer. 2014. "Religion, Politician Identity and Development Outcomes: Evidence from India." Journal of Economic Behavior and Organization 104: 4-17.

7. Bharat, Sheetal. 2012. Where the Runners Went: British Motivations Behind Postal Policy and Allocation in Colonial India. Ph.D. Dissertation, University of California at Riverside.

8. Bogart, Dan, and Latika Chaudhary. 2012. "Railways in Colonial India: An Economic Achievement?" Available at SSRN: http://ssrn.com/abstract=2073256.

9. Botticini, Maristella, and Zvi Eckstein, Zvi. 2005. "Jewish occupational selection: education, restrictions, or minorities?" Journal of Economic History 65(4): 922-948.

10. 2007. "From farmers to merchants, conversions and diaspora: human capital and Jewish history." Journal of the European Economic Association 5(5): 885-926.

11. Cantoni, Davide. 2014. "The Economic Effects of the Protestant Reformation: Testing the Weber Hypothesis in the German Lands." Journal of the European Economic Association, forthcoming 
12. Caselli, Francesco, and Wilbur John Coleman II. 2013. "On the Theory of Ethnic Conflict." Journal of the European Economic Association 11(s1): 161-192.

13. Census of India, 2011. Administrative Atlas of India. Office of the Registrar General \& Census Commissioner, India.

14. Chakrabarti, Jadab Chandra. 1895. The Native States of India. Calcutta: S.K. Shaw.

15. Chattopadhyay, Raghabendra, and Esther Duflo. 2004. "Women as Policy Makers: Evidence from a Randomized Policy Experiment in India." Econometrica 72(5): 14091433.

16. Chaudhary, Latika, and Jared Rubin. 2011. "Reading, Writing, and Religion: Institutions and Human Capital Formation." Journal of Comparative Economics 39(1): 17-33.

17. Chaudhary, Latika. 2009. "Determinants of Primary Schooling in British India." Journal of Economic History 69(1): 269-302.

18. Chaudhary, Latika. 2010. "Taxation and Educational Development: Evidence from British India," Explorations in Economic History 47 (3): 279-293.

19. Chaudhary, Latika. 2012. "Caste, Colonialism and Schooling: Education in British India." Available at SSRN: http://ssrn.com/abstract=2087140.

20. Clarke, Geoffrey. 1921. The Post Office of India and its story. London: John Lane.

21. Coşgel, Metin M., Thomas J. Miceli, and Jared Rubin. 2012a. "Political Legitimacy and Technology Adoption." Journal of Institutional and Theoretical Economics 168(3): 339-361.

22. ___ _ _ _ - 2012b. "The Political Economy of Mass Printing: Legitimacy, Revolt, and Technology Change in the Ottoman Empire." Journal of Comparative Economics 40(3): 357-371.

23. Fearon, James D. 1999. "Why Ethnic Politics and "Pork" Tend to Go Together?" Stanford University Working Paper.

24. Ferguson, Niall. 2002. Empire: The Rise and Demise of the British World Order and the Lessons for Global Power. New York: Basic Books. 
25. Franck, Raphael, and Ilia Rainer. 2012. "Does the leader's ethnicity matter? Ethnic favoritism, education and health in sub-Saharan Africa." American Political Science Review 106(2): 294-325.

26. Gill, Anthony, and Erik Lundsgaarde. 2004. "State Welfare Spending and Religiosity: A Cross-National Analysis." Rationality and Society 16(4): 399-436.

27. Greif, Avner. 1994. "Cultural Beliefs and the Organization of Society: A Historical and Theoretical Reflection on Collectivist and Individualist Societies." Journal of Political Economy 102(5): 912-950.

28. 2006. Institutions and the Path to the Modern Economy. Cambridge: Cambridge University Press.

29. Greif, Avner, and Jared Rubin. 2015. "The Institution Basis of Political Legitimacy and the Origin of the Modern Economy in England." Working Paper.

30. Grier, Robin. 1997. "The Effect of Religion on Economic Development: A Cross National Study of 63 Former Colonies." Kyklos 50(1): 47-62.

31. Guiso, Luigi, Sapienza, Paola, and Zingales, Luigi. 2003. "People's opium? Religion and economic attitudes." Journal of Monetary Economics 50(1): 225-282.

32. House of Commons. 1913. Statement exhibiting the Moral and Material Progress and Condition of India, for 1911-12 and the nine preceding years, being the Fifth Decennial Report (East India: Progress and Condition). London: His Majesty's Stationery Office.

33. Huber, John D., and Piero Stanig. 2011. "Church-State Separation and Redistribution." Journal of Public Economics 95(7-8): 828-836.

34. Hungerman, Daniel M. 2005. "Are Church and State Substitutes? Evidence from the 1996 Welfare Reform." Journal of Public Economics 89: 2245-2267.

35. Hungerman, Daniel M., and Jonathan Gruber 2007. "Faith-Based Charity and Crowd Out During the Great Depression." Journal of Public Economics 91: 1043-1069.

36. Hunter, William Wilson, James Sutherland Cotton, Richard Burn, and William Meyer. 1907. Imperial gazetteer of India. Oxford: Clarendon Press. 
37. Iyer, Lakshmi. 2010. "Direct versus Indirect Colonial Rule in India: Long-Term Consequences." Review of Economics and Statistics 92(4): 693-713.

38. Iyer, Sriya, Chander Velu, and Melvyn Weeks. 2014. "Divine Competition: Religious Organisations and Service Provision in India." Cambridge University Working Paper.

39. Imbens, Guido W., and Donald B. Rubin. 2015. An Introduction to Causal Inference in Statistics, Biomedical and Social Sciences. New York: Cambridge University Press.

40. Iyigun, Murat. 2015. War, Peace, and Prosperity in the Name of God. Chicago, University of Chicago Press.

41. Jeffrey, Robin (ed). 1978. People, Princes and Paramount Power: Society and Politics in the Indian Princely States. New Delhi: Oxford University Press.

42. Jha, Saumitra. 2013. "Trade, Institutions and Ethnic Tolerance: Evidence from South Asia." American Political Science Review 107(4): 806-832.

43. . 2014. "Unfinished Business': Historic Complementarities, Political Competition and Ethnic Violence in Gujarat." Journal of Economic Behavior and Organization 104: 18-36.

44. Johnson, Noel, and Mark Koyama. 2014. "Taxes, Lawyers, and the Decline of Witch Trials in France." Journal of Law and Economics 57(1): 77-112.

45. Khan, Shaharyar M. 2000. The Begums of Bhopal, A Dynasty of Women Rulers in Raj India. London: I.B.Tauris Publishers.

46. Kuran, Timur. 2005. "The Absence of the Corporation in Islamic Law: Origins and Persistence." American Journal of Comparative Law 53: 785-834.

47. . 2011. The Long Divergence: How Islamic Law Held Back the Middle East. Princeton: Princeton University Press.

48. Leuven, Edwin, and Barbara Sianesi. 2003. "PSMATCH2: Stata module to perform full Mahalanobis and propensity score matching, common support graphing, and covariate imbalance testing." Statistical Software Components S432001, Boston College Department of Economics, revised 12 Feb 2014.

49. Malleson, G. B. 1875. An Historical Sketch of the Native States of India in Subsidiary Alliance with the British government, with a Notice of the Mediatized and Minor states. London: Longmans. 
50. Milgrom, Paul, and Chris Shannon. 1994. "Monotone Comparative Statics." Econometrica 62(1): 157-180.

51. Noland, Marcus. 2005. "Religion and Economic Performance." World Development 33(8): 1215-1232.

52. Nurullah, Syed, and J. P. Naik. 1951. A history of education in India during the British period. Bombay: Macmillan.

53. Oak, Mandar and Anand Swamy. 2012. "Myopia or strategic behavior? Indian regimes and the East India Company in late eighteenth century India." Explorations in Economic History 49(3): 352-366.

54. Ramusack, Barbara N. 2004. The New Cambridge History of India III. 6. The Indian Princes and Their States. Cambridge: Cambridge University Press.

55. Ray, Bharati. 1984. "The Genesis of Railway Development in Hyderabad State: A Case Study in Nineteenth Century British Imperialism." Indian Economic \& Social History Review 21: 45-69.

56. Roy, Tirthankar. 2013. An Economic History of Early Modern India. London: Routledge, Taylor \& Francis Group.

57. Rubin, Jared. 2010. "Bills of Exchange, Interest Bans, and Impersonal Exchange in Islam and Christianity." Explorations in Economic History 47(2): 213-227

58. ________. 2011. "Institutions, the Rise of Commerce, and the Persistence of Laws: Interest Restrictions in Islam \& Christianity." Economic Journal 121(557): 1310-1339.

59. Sood, Gagan. 2009. "The informational fabric of eighteenth-century India and the Middle East: Couriers, intermediaries and postal communication." Modern Asian Studies 43(5):1085-1116.

60. Spenkuch, Jörg L. 2011. "The Protestant Ethic and Work: Micro Evidence from Contemporary Germany." Northwestern University Mimeo.

61. Tawney, Richard H. (1926) 1954. Religion and the Rise of Capitalism. New York: Mentor. 
62. Topkis, Donald. 1998. Supermodularity and Complementarity. Princeton: Princeton University Press.

63. Weber, Max. (1905) 2002. The Protestant Ethic and the 'Spirit' of Capitalism. New York: Penguin. 
Figure 1: Map of British India and Princely States, 1911

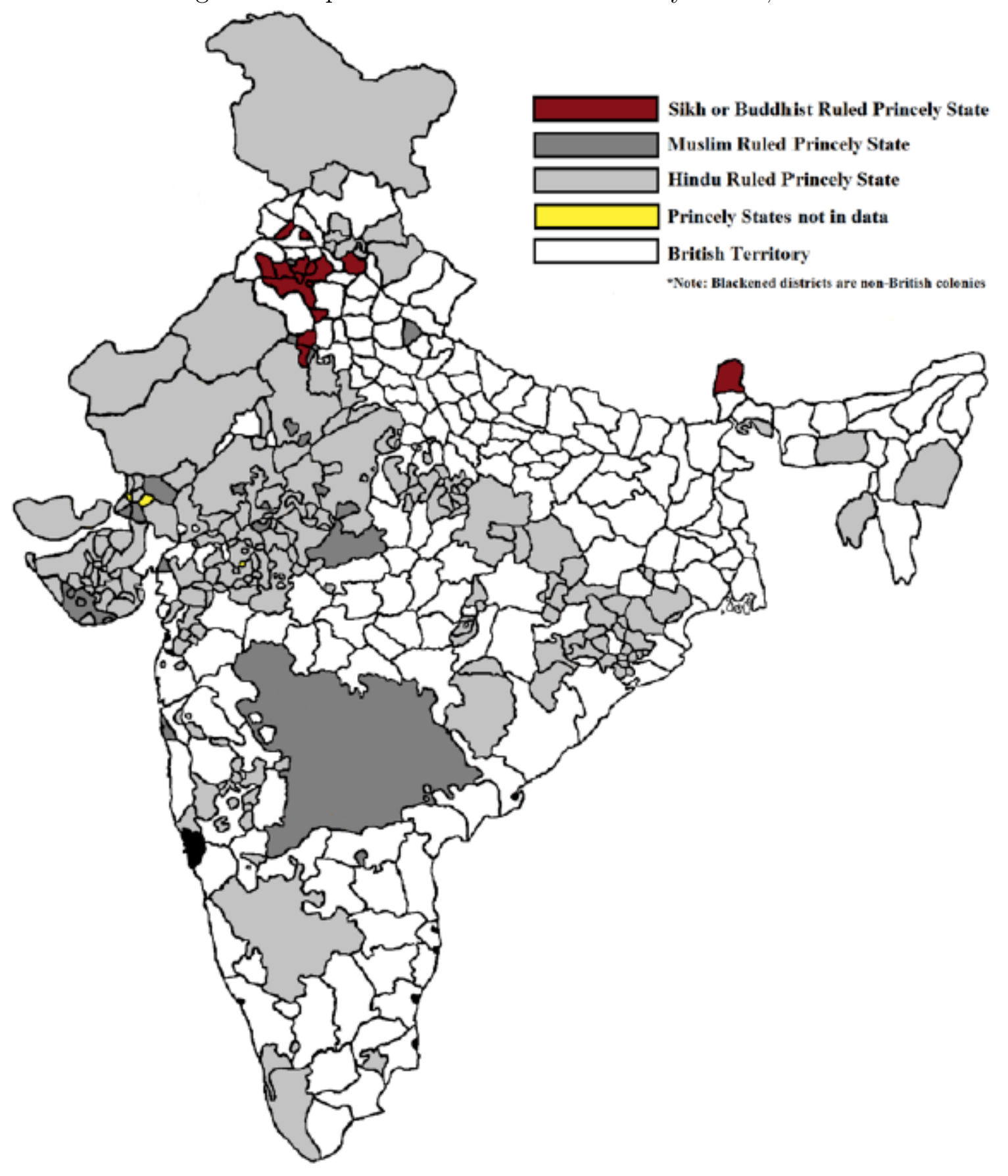


Figure 2: Collapse of Muslim Rule in India

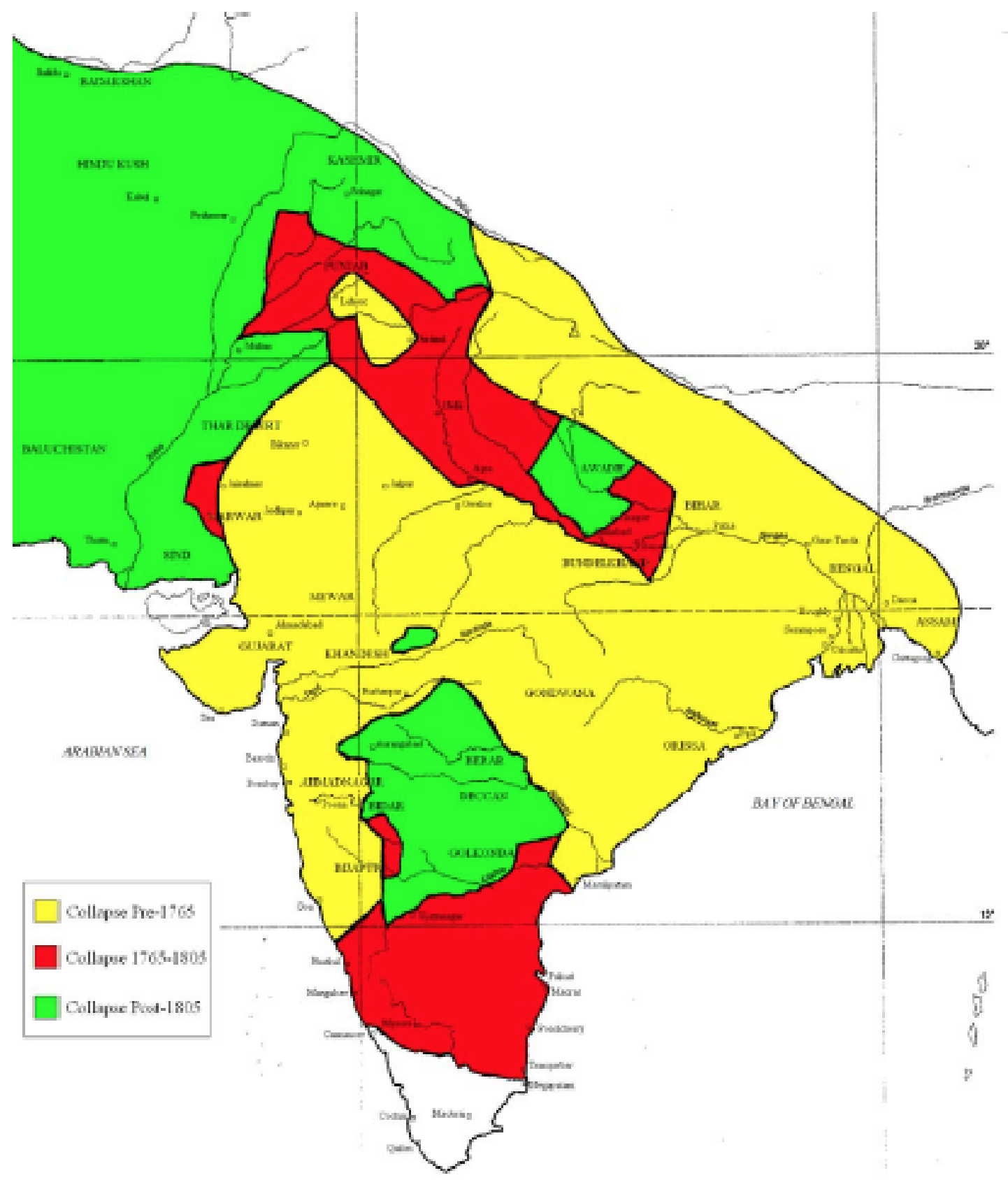

Source: Robinson (1982) 
Figure 3: Histogram of Residuals by Muslim Ruler

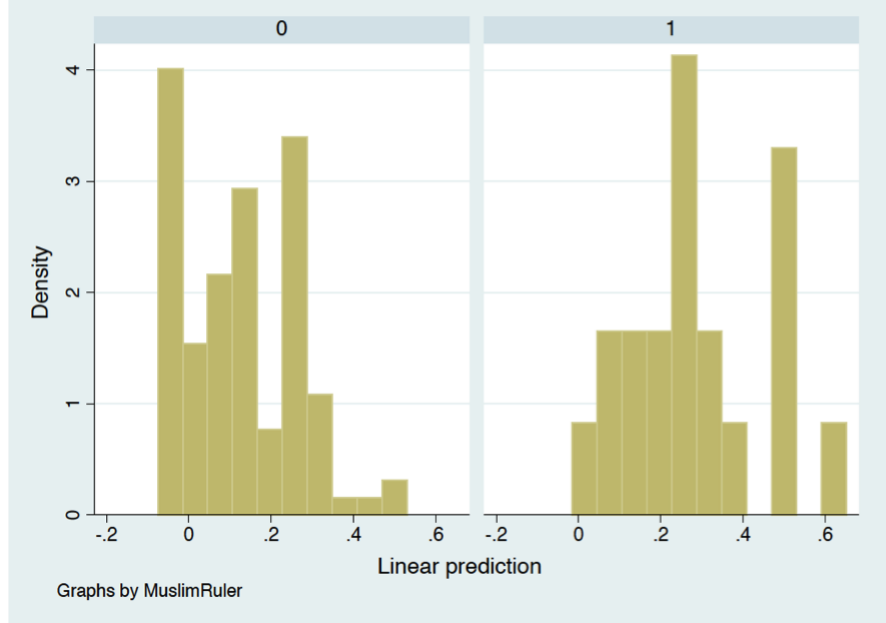

Figure 4: Kernel Density of Residual by Muslim Ruler

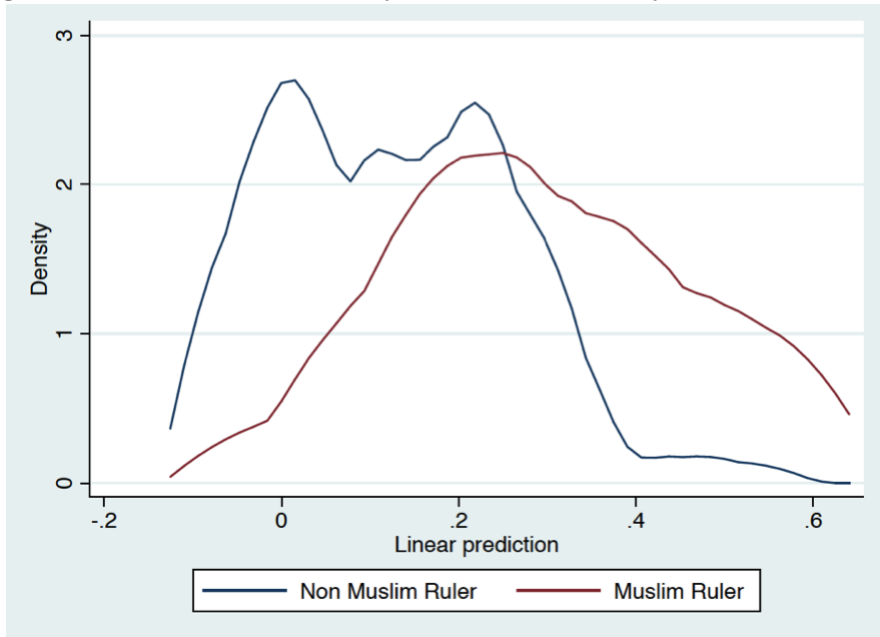




\begin{tabular}{|c|c|c|c|c|c|}
\hline & \multicolumn{2}{|c|}{$\underline{\text { Non-Muslim Ruler }}$} & \multicolumn{2}{|c|}{$\underline{\text { Muslim Ruler }}$} & \multirow[t]{2}{*}{ Diff } \\
\hline & Mean & $\mathrm{SD}$ & Mean & $\mathrm{SD}$ & \\
\hline \multicolumn{6}{|l|}{ Outcomes } \\
\hline Literacy Rate, 1911 & $4.2 \%$ & $3.4 \%$ & $4.6 \%$ & $3.0 \%$ & -0.003 \\
\hline Muslim Literacy Rate, 1911 & $6.3 \%$ & $5.2 \%$ & $6.2 \%$ & $4.2 \%$ & 0.001 \\
\hline Hindu Literacy Rate, 1911 & $4.3 \%$ & $2.8 \%$ & $3.7 \%$ & $2.9 \%$ & 0.006 \\
\hline Muslim Literacy Rate, 1931 & $9.2 \%$ & $6.7 \%$ & $8.4 \%$ & $5.3 \%$ & 0.008 \\
\hline Hindu Literacy Rate, 1931 & $5.7 \%$ & $4.5 \%$ & $5.0 \%$ & $3.4 \%$ & 0.007 \\
\hline Public Schools (1903/04) & 97.8 & 269.7 & 95.4 & 208.0 & 2.4 \\
\hline Pupils (1903/04) & 4,720 & 14,495 & 7,314 & 17,057 & -2594 \\
\hline Railway Ownership (0/1) & $25.3 \%$ & $43.7 \%$ & $38.9 \%$ & $50.2 \%$ & -0.136 \\
\hline Post Office $(0 / 1)$ & $54.5 \%$ & $50.0 \%$ & $38.9 \%$ & $50.2 \%$ & 0.157 \\
\hline \multicolumn{6}{|l|}{ Socio-Economic } \\
\hline Fraction Muslim & $8.9 \%$ & $11.0 \%$ & $22.1 \%$ & $18.2 \%$ & $-0.132 * *$ \\
\hline Fraction Other & $10.5 \%$ & $19.4 \%$ & $5.4 \%$ & $9.4 \%$ & 0.050 \\
\hline Towns/Area & 0.002 & 0.004 & 0.004 & 0.005 & -0.002 \\
\hline Revenues/Area & 551 & 523 & 777 & 125 & $-225.7 *$ \\
\hline Area & 3,531 & 8,715 & 6,468 & 19,375 & $-2,936$ \\
\hline Coastal $(0 / 1)$ & $9.1 \%$ & $28.9 \%$ & $27.8 \%$ & $46.1 \%$ & $-0.187^{*}$ \\
\hline \multicolumn{6}{|l|}{ Institutional } \\
\hline Founded Post-1707 (0/1) & $46.5 \%$ & $50.1 \%$ & $83.3 \%$ & $38.3 \%$ & $-0.369 * *$ \\
\hline \# Gun Salutes & 9.4 & 6.8 & 7.9 & 7.8 & 1.5 \\
\hline Rulers w/ Historical Ties to State $(0 / 1)$ & $90.9 \%$ & $28.9 \%$ & $44.4 \%$ & $51.1 \%$ & $0.465 * *$ \\
\hline Reprimand/Intervention by GOI (01/1) & $28.3 \%$ & $45.3 \%$ & $27.8 \%$ & $46.1 \%$ & 0.005 \\
\hline Post 1805 Collapse of Mughal Rule $(0 / 1)$ & $2.0 \%$ & $14.1 \%$ & $11.1 \%$ & $32.3 \%$ & -0.091 \\
\hline 1765-1805 Collapse of Mughal Rule (0/1) & $12.1 \%$ & $32.8 \%$ & $22.2 \%$ & $42.8 \%$ & -0.101 \\
\hline Observations & \multicolumn{2}{|c|}{99} & \multicolumn{2}{|c|}{18} & \\
\hline
\end{tabular}

Note: See text for sources and details. ${ }^{*} \mathrm{p}<0.05,{ }^{* *} \mathrm{p}<0.01,{ }^{* * *} \mathrm{p}<0.001$ 
TABLE 2: EFFECT OF MUSLIM RULE ON LITERACY RATES, 1911

\begin{tabular}{|c|c|c|c|c|c|c|c|}
\hline & \multicolumn{3}{|c|}{ Total Literacy } & \multicolumn{2}{|c|}{ Hindu Literacy } & \multicolumn{2}{|c|}{ Muslim Literacy } \\
\hline & $(1)$ & $(2)$ & (3) & (4) & $(5)$ & $(6)$ & $(7)$ \\
\hline \multirow[t]{2}{*}{ Muslim Ruler $(\beta 1)$} & $-0.015 * * *$ & -0.007 & -0.001 & $-0.023 * * *$ & $-0.030 * * *$ & 0.010 & -0.002 \\
\hline & [0.006] & {$[0.007]$} & [0.009] & [0.008] & [0.009] & {$[0.016]$} & {$[0.022]$} \\
\hline \multirow[t]{2}{*}{ Fraction Muslim } & $0.042 * *$ & $0.040 * *$ & $0.052 * *$ & $0.103 * * *$ & $0.088 * * *$ & -0.040 & -0.065 \\
\hline & {$[0.017]$} & {$[0.018]$} & {$[0.025]$} & [0.019] & {$[0.022]$} & {$[0.032]$} & [0.048] \\
\hline \multirow[t]{2}{*}{ Fraction Other } & 0.006 & 0.000 & -0.001 & 0.013 & $0.014 *$ & $0.037 *$ & $0.038 *$ \\
\hline & {$[0.009]$} & {$[0.008]$} & {$[0.008]$} & {$[0.008]$} & {$[0.008]$} & {$[0.020]$} & {$[0.020]$} \\
\hline \multirow[t]{2}{*}{ Towns/Area } & 0.812 & $1.404 * * *$ & $1.377 * * *$ & 0.073 & 0.107 & $-2.049 *$ & $-1.988 *$ \\
\hline & {$[0.510]$} & {$[0.490]$} & {$[0.500]$} & {$[0.405]$} & {$[0.411]$} & [1.099] & [1.106] \\
\hline \multirow[t]{2}{*}{ Ln-Revenue/Area } & $0.004 *$ & 0.003 & 0.002 & 0.001 & 0.001 & 0.002 & 0.002 \\
\hline & {$[0.002]$} & {$[0.002]$} & {$[0.002]$} & {$[0.002]$} & {$[0.002]$} & {$[0.003]$} & [0.004] \\
\hline \multirow[t]{2}{*}{ Area } & $-0.000 *$ & $-0.000 * *$ & $-0.000 * *$ & $-0.000 * *$ & $-0.000^{*}$ & $-0.000^{*}$ & $-0.000 *$ \\
\hline & {$[0.000]$} & {$[0.000]$} & {$[0.000]$} & {$[0.000]$} & {$[0.000]$} & {$[0.000]$} & {$[0.000]$} \\
\hline \multirow[t]{2}{*}{ Coastal $(0 / 1)$} & $0.045^{* * *}$ & $0.037 * * *$ & $0.037 * * *$ & $0.020 * *$ & $0.020 * *$ & 0.013 & 0.014 \\
\hline & {$[0.010]$} & {$[0.010]$} & {$[0.011]$} & {$[0.008]$} & {$[0.008]$} & {$[0.025]$} & [0.025] \\
\hline \multirow{2}{*}{$\begin{array}{l}\text { Founded Post } 1707 \\
(0 / 1)\end{array}$} & & $-0.011 * *$ & $-0.011 * *$ & -0.005 & -0.005 & $-0.016^{*}$ & $-0.015^{*}$ \\
\hline & & {$[0.005]$} & {$[0.005]$} & {$[0.004]$} & {$[0.004]$} & {$[0.008]$} & {$[0.008]$} \\
\hline \multirow[t]{2}{*}{ \# Gun Salutes } & & $0.001 * * *$ & $0.001 * *$ & 0.000 & 0.000 & 0.000 & 0.000 \\
\hline & & {$[0.000]$} & {$[0.000]$} & {$[0.000]$} & {$[0.000]$} & [0.001] & {$[0.001]$} \\
\hline \multirow{2}{*}{$\begin{array}{l}\text { Rulers w/ Historical } \\
\text { Ties to State }(0 / 1)\end{array}$} & & 0.001 & 0.001 & -0.007 & -0.007 & 0.002 & 0.002 \\
\hline & & {$[0.006]$} & {$[0.006]$} & {$[0.006]$} & {$[0.006]$} & {$[0.012]$} & [0.012] \\
\hline \multirow{2}{*}{$\begin{array}{l}\text { Reprimand/Interventio } \\
\mathrm{n} \text { by GOI }(01 / 1)\end{array}$} & & 0.005 & 0.006 & 0.005 & 0.004 & 0.002 & 0.001 \\
\hline & & {$[0.005]$} & {$[0.005]$} & {$[0.004]$} & {$[0.004]$} & {$[0.007]$} & [0.007] \\
\hline \multirow{2}{*}{$\begin{array}{l}\text { Post } 1805 \text { Collapse of } \\
\text { Mughal Rule }(0 / 1)\end{array}$} & & -0.011 & -0.014 & -0.014 & -0.011 & 0.041 & 0.046 \\
\hline & & [0.009] & {$[0.011]$} & {$[0.015]$} & {$[0.016]$} & {$[0.033]$} & [0.036] \\
\hline \multirow{2}{*}{$\begin{array}{l}\text { 1765-1805 Collapse of } \\
\text { Mughal Rule }(0 / 1)\end{array}$} & & -0.005 & -0.007 & $-0.018^{*}$ & -0.016 & -0.022 & -0.019 \\
\hline & & {$[0.008]$} & {$[0.009]$} & {$[0.011]$} & {$[0.011]$} & {$[0.014]$} & [0.014] \\
\hline Muslim Ruler * & & & -0.031 & & 0.038 & & 0.063 \\
\hline Fraction Muslim ( $\beta 2)$ & & & {$[0.032]$} & & [0.029] & & {$[0.058]$} \\
\hline Observations & 116 & 116 & 116 & 106 & 106 & 105 & 105 \\
\hline R-squared & 0.584 & 0.634 & 0.636 & 0.748 & 0.753 & 0.548 & 0.551 \\
\hline
\end{tabular}

Robust standard errors in brackets. $* * * \mathrm{p}<0.01,{ }^{*} * \mathrm{p}<0.05,{ }^{*} \mathrm{p}<0.1$

All the regressions include region fixed effects. 
TABLE 3: EFFECT OF MUSLIM RULE ON LITERACY RATES, 1931

\begin{tabular}{|c|c|c|c|c|c|c|}
\hline & \multicolumn{3}{|c|}{ Hindu Literacy } & \multicolumn{3}{|c|}{ Muslim Literacy } \\
\hline & $(1)$ & $(2)$ & (3) & $(4)$ & $(5)$ & $(6)$ \\
\hline \multirow[t]{2}{*}{ Muslim Ruler $(\beta 1)$} & $-0.037 * * *$ & $-0.031 * * *$ & $-0.028 * *$ & 0.000 & 0.007 & -0.006 \\
\hline & [0.007] & {$[0.010]$} & {$[0.014]$} & {$[0.011]$} & {$[0.017]$} & {$[0.022]$} \\
\hline \multirow[t]{2}{*}{ Fraction Muslim } & $0.098 * * *$ & $0.086 * * *$ & $0.091 * *$ & $-0.083 * *$ & $-0.087 * *$ & $-0.115^{* *}$ \\
\hline & {$[0.023]$} & {$[0.025]$} & {$[0.036]$} & {$[0.040]$} & {$[0.035]$} & {$[0.049]$} \\
\hline \multirow[t]{2}{*}{ Fraction Other } & 0.033 & 0.023 & 0.023 & $0.086 * * *$ & $0.080 * *$ & $0.082 * *$ \\
\hline & {$[0.022]$} & {$[0.020]$} & {$[0.020]$} & {$[0.031]$} & {$[0.032]$} & {$[0.033]$} \\
\hline \multirow[t]{2}{*}{ Towns/Area } & $1.315^{* *}$ & $2.092 * * *$ & $2.079 * * *$ & $-3.676 * *$ & $-2.944 * *$ & $-2.869 *$ \\
\hline & {$[0.633]$} & {$[0.579]$} & {$[0.588]$} & [1.493] & {$[1.431]$} & {$[1.448]$} \\
\hline \multirow[t]{2}{*}{ Ln-Revenue/Area } & $0.006 * *$ & 0.003 & 0.003 & $0.010^{*}$ & $0.009^{*}$ & $0.009 *$ \\
\hline & {$[0.003]$} & {$[0.002]$} & {$[0.003]$} & {$[0.005]$} & {$[0.005]$} & {$[0.005]$} \\
\hline \multirow[t]{2}{*}{ Area } & -0.000 & -0.000 & -0.000 & 0.000 & -0.000 & -0.000 \\
\hline & {$[0.000]$} & {$[0.000]$} & {$[0.000]$} & {$[0.000]$} & {$[0.000]$} & {$[0.000]$} \\
\hline \multirow[t]{2}{*}{ Coastal (0/1) } & $0.054 * * *$ & $0.046^{* * *}$ & $0.046^{* * *}$ & 0.003 & -0.004 & -0.002 \\
\hline & {$[0.012]$} & [0.012] & [0.012] & {$[0.020]$} & {$[0.022]$} & {$[0.022]$} \\
\hline \multirow[t]{2}{*}{ Founded Post 1707 (0/1) } & & 0.000 & 0.000 & & $-0.021 *$ & -0.020 \\
\hline & & {$[0.006]$} & {$[0.006]$} & & {$[0.013]$} & {$[0.013]$} \\
\hline \multirow[t]{2}{*}{ \# Gun Salutes } & & $0.001 * * *$ & $0.001 * *$ & & 0.000 & 0.001 \\
\hline & & {$[0.001]$} & {$[0.001]$} & & {$[0.001]$} & {$[0.001]$} \\
\hline \multirow{2}{*}{$\begin{array}{l}\text { Rulers w/ Historical Ties } \\
\text { to State }(0 / 1)\end{array}$} & & -0.002 & -0.002 & & -0.006 & -0.005 \\
\hline & & {$[0.012]$} & {$[0.012]$} & & {$[0.018]$} & {$[0.018]$} \\
\hline \multirow{2}{*}{$\begin{array}{l}\text { Reprimand/Intervention } \\
\text { by GOI }(01 / 1)\end{array}$} & & 0.005 & 0.005 & & $0.020 *$ & 0.019 \\
\hline & & {$[0.006]$} & {$[0.006]$} & & {$[0.012]$} & {$[0.012]$} \\
\hline \multirow{2}{*}{$\begin{array}{l}\text { Post } 1805 \text { Collapse of } \\
\text { Mughal Rule }(0 / 1)\end{array}$} & & -0.021 & -0.022 & & 0.006 & 0.012 \\
\hline & & {$[0.014]$} & {$[0.016]$} & & {$[0.019]$} & {$[0.021]$} \\
\hline \multirow{2}{*}{$\begin{array}{l}\text { 1765-1805 Collapse of } \\
\text { Mughal Rule }(0 / 1)\end{array}$} & & -0.019 & -0.020 & & $-0.034 * *$ & $-0.030 * *$ \\
\hline & & {$[0.015]$} & {$[0.017]$} & & {$[0.014]$} & {$[0.013]$} \\
\hline Muslim Ruler * & & & -0.014 & & & 0.071 \\
\hline Fraction Muslim ( $\beta 2)$ & & & {$[0.051]$} & & & {$[0.056]$} \\
\hline Observations & 114 & 114 & 114 & 113 & 113 & 113 \\
\hline R-squared & 0.578 & 0.623 & 0.623 & 0.437 & 0.483 & 0.486 \\
\hline
\end{tabular}

Robust standard errors in brackets. ${ }^{* * *} \mathrm{p}<0.01,{ }^{* *} \mathrm{p}<0.05,{ }^{*} \mathrm{p}<0.1$

All the regressions include region fixed effects. 
TABLE 4: EFFECT OF MUSLIM RULE ON SCHOOLS AND PUPILS, 1903/04

\begin{tabular}{|c|c|c|c|c|c|c|}
\hline & \multicolumn{3}{|c|}{ Schools } & \multicolumn{3}{|c|}{ Pupils } \\
\hline & $(1)$ & $(2)$ & (3) & (4) & (5) & $(6)$ \\
\hline \multirow[t]{2}{*}{ Muslim Ruler ( $\beta 1)$} & -12 & $-79 *$ & -71 & -493 & $-5,288 *$ & $-5,076^{*}$ \\
\hline & {$[38]$} & [47] & {$[52]$} & {$[2,554]$} & {$[2,904]$} & {$[2,903]$} \\
\hline \multirow[t]{2}{*}{ Ln-Revenue/Area } & & $36^{* *}$ & 17 & & $1,292 * *$ & 1,008 \\
\hline & & {$[17]$} & [13] & & {$[517]$} & [740] \\
\hline \multirow[t]{2}{*}{ Area } & & $0.006 *$ & 0.003 & & 0.244 & 0.229 \\
\hline & & {$[0.004]$} & [0.003] & & [0.192] & {$[0.160]$} \\
\hline \multirow[t]{2}{*}{ Coastal $(0 / 1)$} & & $166^{*}$ & 101 & & $10,439 *$ & $9,007^{*}$ \\
\hline & & [97] & {$[88]$} & & {$[5,335]$} & {$[5,329]$} \\
\hline \multirow[t]{2}{*}{ Founded Post 1707 (0/1) } & & & -8 & & & 1,558 \\
\hline & & & {$[33]$} & & & {$[1,885]$} \\
\hline \multirow[t]{2}{*}{ \# Gun Salutes } & & & $11 * * *$ & & & $295^{* * *}$ \\
\hline & & & [4] & & & {$[88]$} \\
\hline \multirow{2}{*}{$\begin{array}{l}\text { Rulers } w / \text { Historical Ties to } \\
\text { State }(0 / 1)\end{array}$} & & & -107 & & & 708 \\
\hline & & & {$[78]$} & & & {$[1,401]$} \\
\hline \multirow{2}{*}{$\begin{array}{l}\text { Reprimand/Intervention by } \\
\text { GOI }(01 / 1)\end{array}$} & & & 55 & & & 505 \\
\hline & & & {$[40]$} & & & {$[2,002]$} \\
\hline \multirow{2}{*}{$\begin{array}{l}\text { Post } 1805 \text { Collapse of } \\
\text { Mughal Rule }(0 / 1)\end{array}$} & & & -74 & & & $-2,405$ \\
\hline & & & [132] & & & {$[7,416]$} \\
\hline \multirow{2}{*}{$\begin{array}{l}\text { 1765-1805 Collapse of } \\
\text { Mughal Rule }(0 / 1)\end{array}$} & & & -144 & & & -239 \\
\hline & & & {$[121]$} & & & {$[1,962]$} \\
\hline Observations & 98 & 98 & 98 & 81 & 81 & 81 \\
\hline R-squared & 0.435 & 0.513 & 0.614 & 0.642 & 0.702 & 0.716 \\
\hline
\end{tabular}

Robust standard errors in brackets. $* * * \mathrm{p}<0.01,{ }^{* *} \mathrm{p}<0.05,{ }^{*} \mathrm{p}<0.1$

All the regressions include region fixed effects. 
TABLE 5: EFFECT OF MUSLIM RULE ON RAILWAY AND POST OFFICE PROVISION

\begin{tabular}{|c|c|c|c|c|c|c|}
\hline & \multicolumn{3}{|c|}{ Post Office $(0 / 1)$} & \multicolumn{3}{|c|}{ Railway Ownership (0/1) } \\
\hline & $(1)$ & $(2)$ & (3) & $(4)$ & $(5)$ & $(6)$ \\
\hline \multirow[t]{2}{*}{ Muslim Ruler $(\beta 1)$} & -0.066 & 0.151 & 0.036 & -0.003 & 0.040 & -0.041 \\
\hline & {$[0.117]$} & {$[0.110]$} & [0.143] & {$[0.136]$} & {$[0.151]$} & [0.198] \\
\hline \multirow[t]{2}{*}{ Fraction Muslim } & 0.186 & 0.050 & -0.183 & -0.194 & -0.184 & -0.348 \\
\hline & {$[0.337]$} & [0.296] & {$[0.374]$} & {$[0.287]$} & {$[0.311]$} & {$[0.408]$} \\
\hline \multirow[t]{2}{*}{ Fraction Other } & $0.598 * *$ & $0.453^{*}$ & $0.465^{*}$ & $0.383 * *$ & 0.280 & 0.288 \\
\hline & {$[0.274]$} & {$[0.251]$} & {$[0.249]$} & {$[0.163]$} & {$[0.171]$} & {$[0.174]$} \\
\hline \multirow[t]{2}{*}{ Towns/Area } & -1.959 & $14.196^{*}$ & $14.717 *$ & $-24.291 * * *$ & $-15.419 * *$ & $-15.054 * *$ \\
\hline & [7.598] & {$[7.180]$} & [7.419] & [8.189] & {$[6.845]$} & [6.864] \\
\hline \multirow[t]{2}{*}{ Ln-Revenue/Area } & 0.026 & -0.020 & -0.014 & $0.127 * * *$ & $0.084 * *$ & $0.088 * *$ \\
\hline & {$[0.035]$} & {$[0.034]$} & {$[0.034]$} & {$[0.033]$} & {$[0.035]$} & {$[0.037]$} \\
\hline \multirow[t]{2}{*}{ Area } & $0.000 * *$ & 0.000 & 0.000 & $0.000 * * *$ & $0.000 * *$ & $0.000 * *$ \\
\hline & {$[0.000]$} & {$[0.000]$} & {$[0.000]$} & {$[0.000]$} & {$[0.000]$} & {$[0.000]$} \\
\hline \multirow[t]{2}{*}{ Coastal $(0 / 1)$} & -0.014 & $-0.217 * *$ & $-0.203 * *$ & $0.409 * * *$ & $0.300 * *$ & $0.309 * *$ \\
\hline & {$[0.108]$} & {$[0.098]$} & {$[0.102]$} & {$[0.148]$} & {$[0.146]$} & {$[0.147]$} \\
\hline \multirow[t]{2}{*}{ Founded Post 1707 (0/1) } & & $-0.169 * *$ & $-0.164 * *$ & & 0.017 & 0.021 \\
\hline & & {$[0.077]$} & {$[0.078]$} & & {$[0.070]$} & {$[0.070]$} \\
\hline \multirow[t]{2}{*}{ \# Gun Salutes } & & $0.031 * * *$ & $0.031 * * *$ & & $0.023 * * *$ & $0.023 * * *$ \\
\hline & & {$[0.006]$} & {$[0.006]$} & & {$[0.006]$} & {$[0.006]$} \\
\hline \multirow{2}{*}{$\begin{array}{l}\text { Rulers w/ Historical Ties } \\
\text { to State }(0 / 1)\end{array}$} & & 0.094 & 0.095 & & -0.022 & -0.022 \\
\hline & & {$[0.110]$} & {$[0.108]$} & & {$[0.119]$} & {$[0.118]$} \\
\hline \multirow{2}{*}{$\begin{array}{l}\text { Reprimand/Intervention } \\
\text { by GOI }(01 / 1)\end{array}$} & & 0.109 & 0.100 & & -0.007 & -0.013 \\
\hline & & {$[0.075]$} & {$[0.075]$} & & {$[0.082]$} & {$[0.083]$} \\
\hline \multirow{2}{*}{$\begin{array}{l}\text { Post } 1805 \text { Collapse of } \\
\text { Mughal Rule }(0 / 1)\end{array}$} & & -0.428 & -0.368 & & -0.103 & -0.061 \\
\hline & & {$[0.357]$} & {$[0.367]$} & & {$[0.373]$} & {$[0.384]$} \\
\hline \multirow{2}{*}{$\begin{array}{l}\text { 1765-1805 Collapse of } \\
\text { Muslim Rule }(0 / 1)\end{array}$} & & -0.089 & -0.056 & & 0.105 & 0.129 \\
\hline & & {$[0.132]$} & {$[0.134]$} & & {$[0.164]$} & {$[0.175]$} \\
\hline Muslim Ruler * & & & 0.610 & & & 0.428 \\
\hline Fraction Muslim ( $\beta 2)$ & & & {$[0.429]$} & & & {$[0.605]$} \\
\hline Observations & 117 & 117 & 117 & 117 & 117 & 117 \\
\hline R-squared & 0.451 & 0.591 & 0.595 & 0.421 & 0.502 & 0.504 \\
\hline
\end{tabular}

Robust standard errors in brackets. ${ }^{* * *} \mathrm{p}<0.01,{ }^{* *} \mathrm{p}<0.05,{ }^{*} \mathrm{p}<0.1$

All the regressions include region fixed effects. 
TABLE 6: Comparison of Railways in 1911

\begin{tabular}{lccc}
\hline \hline & Muslim Ruler & Non-Muslim Ruler & t-statistic \\
\hline Mileage & 111 & 117 & 0.078 \\
Mileage: Standard Gauge & $(77.45)$ & $(28.57)$ & \\
& 51.76 & 17.17 & -0.936 \\
Mileage: Metre Gauge & $(35.80)$ & $(9.18)$ & \\
& 59.25 & 97.02 & 0.676 \\
Mileage/Area & $(43.55)$ & $(34.94)$ & \\
Capital/Mile (in Rupees) & 0.019 & 0.027 & 0.939 \\
& $(0.01)$ & $(0.01)$ & \\
Year of First Opening & 59,773 & 51,470 & -0.732 \\
Organization & $(9076)$ & $(6802)$ & \\
Worked by Government of India & 1893 & 1896 & 0.640 \\
& $(4)$ & $(2)$ & \\
Worked by Private Company & 0.22 & 0.14 & -0.491 \\
Worked by Princely State & $(0.15)$ & $(0.07)$ & \\
& 0.56 & 0.43 & -0.635 \\
Observations & $(0.18)$ & $(0.10)$ & \\
& 0.22 & 0.43 & 1.178 \\
& $(0.15)$ & $(0.10)$ & \\
\hline
\end{tabular}

Notes: Administration Report of the Railways in India 1911, standard deviation in brackets. 
TABLE 7: INVERSE PROBABILITY MATCHING

\begin{tabular}{|c|c|c|c|c|c|c|c|c|}
\hline & \multicolumn{2}{|c|}{1911 Literacy } & \multicolumn{2}{|c|}{1931 Literacy } & \multirow{2}{*}{ Railway } & \multirow{2}{*}{ Post Office } & \multirow{2}{*}{ Schools } & \multirow{2}{*}{ Pupils } \\
\hline & Hindu & Muslim & Hindu & Muslim & & & & \\
\hline Muslim Ruler $(\beta 1)$ & $\begin{array}{c}-0.029 * * * \\
{[0.007]}\end{array}$ & $\begin{array}{c}-0.004 \\
{[0.013]}\end{array}$ & $\begin{array}{c}-0.030 * * * \\
{[0.010]}\end{array}$ & $\begin{array}{l}-0.015 \\
{[0.014]}\end{array}$ & $\begin{array}{c}0.177 \\
{[0.118]}\end{array}$ & $\begin{array}{c}0.200 * * \\
{[0.093]}\end{array}$ & $\begin{array}{l}-52 \\
{[50]}\end{array}$ & $\begin{array}{c}-1,463 \\
{[1,155]}\end{array}$ \\
\hline $\begin{array}{l}\text { Observations } \\
\text { R-squared }\end{array}$ & $\begin{array}{c}106 \\
0.689\end{array}$ & $\begin{array}{c}105 \\
0753\end{array}$ & $\begin{array}{c}114 \\
0.567\end{array}$ & $\begin{array}{c}113 \\
0.665\end{array}$ & $\begin{array}{c}117 \\
0.526\end{array}$ & $\begin{array}{c}117 \\
0.594\end{array}$ & $\begin{array}{c}98 \\
0.644\end{array}$ & $\begin{array}{c}81 \\
0.767\end{array}$ \\
\hline
\end{tabular}

Robust standard errors in brackets. $* * * \mathrm{p}<0.01, * * \mathrm{p}<0.05, * \mathrm{p}<0.1$

All the regressions include region fixed effects, and the same set of controls as in specifications 3 and 6 for literacy, railways, post offices schools and pupils in Tables35 respectively. 


\begin{tabular}{|c|c|c|}
\hline State & Region & Founding of State \\
\hline Balasinor & Bombay & $\begin{array}{l}\text { The ruling family descends from Sher Khan Babi (Babi Dynasty), a distinguished Mughal officer. When Mughal rule declined he successfully overthrew the Mughal governor around } \\
1735 \text { and established his independent state. On the death of his son, Salabat Khan, the territory was divided with Junagadh going to the younger son of Salabat Khan and Balasinor to the } \\
\text { older son. }\end{array}$ \\
\hline Cambay & Bombay & The ruling family descends from Momin Khan, one of the last Mughal governors of Gujarat. The state was established during the decline of the Mughal Empire around 1730. \\
\hline Jafrabad & Bombay & $\begin{array}{l}\text { The state became independent under local authority in } 1736 \text { when Mughal rule declined in this region. The locals took to piracy and were ousted by the Nawab of Janjira. The state was } \\
\text { sold to a Sunni Muslim of Abyssinian descent in 1759, but he was unable to control the state. It was transferred to the Nawab of Janjira, who sent the former ruler to serve as his } \\
\text { governor. It is a dependent state of Janjira. }\end{array}$ \\
\hline Janjira & Bombay & $\begin{array}{l}\text { Muslim rule in this predates the Mughal Empire and is of foreign origin. The Abyssinians (working for the Nizam Shahi kings of Ahmedabad) established their control over Janjira in } \\
1489 \text {, it became a part of Bijapur State but remained under local Abyssinian rule. The state allied with the Mughal Empire and was never ruled by the Marathas despite numerous } \\
\text { attempts. (Many Abyssinians were brought as slaves by the Portuguese from Africa and converted to Islam in India. They often worked as mercenaries for local rulers.) }\end{array}$ \\
\hline Junagadh & Bombay & $\begin{array}{l}\text { The ruling family descends from Sher Khan Babi (Babi Dynasty), a distinguished Mughal officer. When Mughal rule declined he successfully overthrew the Mughal governor around } \\
1735 \text { and established his independent state. On the death of his son, Salabat Khan, the territory was divided with Junagadh going to the younger son of Salabat Khan and Balasinor to the } \\
\text { older son. }\end{array}$ \\
\hline Palanpur & Bombay & $\begin{array}{l}\text { The founders belonged to the Lohani Afghan Dynasty. They came to rule the state during the decline of the Mughal Empire, but were attacked by the Marathas. They were able to protect } \\
\text { themselves from the Marathas with help from the East India Company. }\end{array}$ \\
\hline Radhanpur & Bombay & $\begin{array}{l}\text { The ruling family descends from the Babi Dynasty (see Balasinor and Junagadh). The state emerged under independent rule following the decline of the Mughal Empire and the rise of } \\
\text { the Marathas. Although the founder Kamal-ud-din Khan lost some territory to the Marathas, he received Radhanpur as a jagir. }\end{array}$ \\
\hline Savanur & Bombay & $\begin{array}{l}\text { In 1680, Abdul Rauf Khan (Muslim of Pathan origin) received a jagir of which Savanur was one part from Aurangzeb. The ruling family was attacked by Tipu Sultan (Mysore) but the } \\
\text { Marathas helped the Nawab regain some of his territory. Finally, the British recognized his right to rule Savanur on account of their loyalty during the last Anglo-Maratha war. }\end{array}$ \\
\hline Khairpur & Bombay (Sind) & The founder descends from the Talpur clan of Sindh. The state was established around 1775 during succession disputes after the death of the clan chief, Mir Bahram Khan. \\
\hline Baoni & CIA & Founded by the Nizam of Hyderabad's grandson (Asaf Jah) around 1784 as a jagir from the Marathas. The British recognized his rule in 1806. \\
\hline Bhopal & CIA & $\begin{array}{l}\text { The founder, Dost Mohammad Kahn, was an Afghan who came to India following the death of Aurangzeb in } 1707 \text { and worked for the Mughal army. He established independent rule in } \\
\text { Bhopal by offering protection to the local population. }\end{array}$ \\
\hline Jaora & CIA & $\begin{array}{l}\text { Gafur Khan (brother in law of Amir Khan - Tonk State), a mercenary of Afgan origins fought on behalf of the Marathas especially the Holkar and received the state in exchange for his } \\
\text { services. }\end{array}$ \\
\hline Banganpalle & Madras & $\begin{array}{l}\text { The state was under the Mughal Empire and then Hyderabad (as a fief). The area was ceded to the East India Company by Hyderabad, but then restored by the Company to the original } \\
\text { family, descendants of Faiz Ali Khan. }\end{array}$ \\
\hline Bahawalpur & Punjab & $\begin{array}{l}\text { The founding family comes from Sind and descends from the Abbasid Caliphs of Egypt. The state became independent during the break up of the Durrani Empire in India (Last Afghan } \\
\text { Empire) that had originally gained control of the territory from the Mughals. }\end{array}$ \\
\hline Dujana & Punjab & $\begin{array}{l}\text { The founder, Yusufzai Khan of Pathan origin, was awarded the state as a land grant from Lord Lake (British military commander-in-chief) in 1806. He worked for Lord Lake and for the } \\
\text { Marathas before that. }\end{array}$ \\
\hline Loharu & Punjab & $\begin{array}{l}\text { The founder Abmad Baksh Khan worked for the Mughals and the family were nobles in Aurangzeb's court. The state was a gift from Alwar and the East India Company for his loyalty in } \\
\text { fighting against the Bharapur State Jats. }\end{array}$ \\
\hline Malerkotla & Punjab & The founder Bayazid Khan was part of the Mughal army. He supposedly saved Aurangzeb's life and in exchange was allowed to establish his independent rule in the state. \\
\hline Patuadi & Punjab & $\begin{array}{l}\text { The founder, Talab Faiz Khan worked first for the Marathas and then Lord Lake (British military commander-in-chief). He received Pataudi for perpetuity from Lord Lake. The family } \\
\text { was originally settled in Patiala (a Sikh Princely State). }\end{array}$ \\
\hline Tonk & Rajputana & $\begin{array}{l}\text { The founder Amir Khan was an Afghan mercenary who fought on behalf of other Muslim leaders and then the Marathas in the late } 18 \text { th century. He received the territory of Tonk from } \\
\text { Holkar (one of the Maratha chiefs) in exchange for his services. }\end{array}$ \\
\hline Hyderabad & South & $\begin{array}{l}\text { A former province of the Mughal Empire. The state was founded by Asaf Jah, a military noble in Aurangzeb's court and the provincial governor of Hyderabad, who became strong } \\
\text { enough during the decline of the Mughal Emperor to establish Hyderabad as an independent state in the early } 1700 \mathrm{~s} \text {. }\end{array}$ \\
\hline Rampur & UP & $\begin{array}{l}\text { The state was founded by the Rohilla Afghans (Pashtuns) after the Rohilla War of 1774-75 against the Nawabs of Oudh. They lost substantial territory in this war and established } \\
\text { Rampur with the help of the British. }\end{array}$ \\
\hline
\end{tabular}

* Jagir was a type of land grant (transferable) awarded by kings to military elites and allowed the holder to collect tax revenues from the area. 